\title{
Is It Possible to Restore a Heavily Polluted, Shallow, Urban Lake?
}

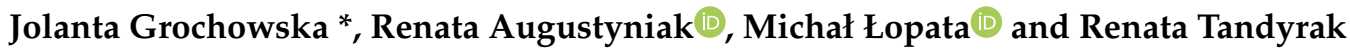

Department of Water Protection Engineering and Environmental Microbiology, Institute of Engineering and Environmental Protection, University of Warmia and Mazury, St. Prawocheńskiego 1, 10-720 Olsztyn, Poland; rbrzoza@uwm.edu.pl (R.A.); michal.lopata@uwm.edu.pl (M.Ł.); renatat@uwm.edu.pl (R.T.)

* Correspondence: jgroch@uwm.edu.pl

Received: 17 April 2020; Accepted: 25 May 2020; Published: 27 May 2020

\begin{abstract}
The research was carried out on Karczemne Lake, a water reservoir located in Kartuzy (northern Poland, Pomeranian Lake District). Monitoring of the water and bottom sediment of Karczemne Lake showed a very high level of contamination of the reservoir by a long-term inflow of untreated municipal sewage. The trophic status index of total phosphorus (TP) was unusually high at 101, and the TP content in the bottom sediments-31 $\mathrm{mg} \mathrm{g}^{-1}$ (dry weight) — was the highest value recorded worldwide in a lake. Based on the monitoring results, to achieve constant improvement of the water quality, we recommend a completely new, safe and economically justified method of bottom sediment removal and management. A very important aspect of this method is the prevention of uncontrolled sewage discharge back into the lake basin. Removed sediment with interstitial water will be pumped through a pipeline and transported to a sewage treatment plant. In the sediment mining field in which the sludge will be removed, the first phase of phosphorus inactivation will be carried out to chemically precipitate pollutants distributed in the water column as a result of sediment resuspension. After the deepening of the entire lake basin, the method of phosphorus inactivation will be carried out on the entire surface of the lake as the next stage of restoration. A supporting activity will be biomanipulation. Before the restoration is started, the municipal sewerage system will be modernized.
\end{abstract}

Keywords: urban lake; restoration; dredging; phosphorus inactivation; biomanipulation

\section{Introduction}

Strong anthropopressure in the catchment areas of lakes (urbanization, industrialization, deforestation and intensive livestock), which stimulates an increased supply of nutrients to waters, causes the acceleration of eutrophication [1-3]. Accelerated eutrophication is exemplified by strong cyanobacterial blooms, species depletion at all trophic levels, the disappearance of valuable fish species and the deterioration of the taste and smell of the water, which leads to the cessation of the reservoir being used for municipal and recreational purposes [4-6]. A sign of excessive eutrophy of the lake is an increase in nutrient concentrations (nitrogen and phosphorus) in the water and an uneven distribution of the amount of oxygen in the water column [7-9]. The surface layers of the reservoir are usually saturated with oxygen, while at the bottom, anaerobic conditions prevail, promoting the release of nutrients from bottom sediments. In oligotrophic and mesotrophic lakes, bottom sediments are a "trap" that bind excess nutrients, especially phosphorus. In degraded lakes, in which the bottom water layers are deoxygenated and therefore accompanied by a reduction in redox potential, the reverse process takes place. The stored substances, such as nutrients, are released into the near-bottom water layers [10-12]. This phenomenon is called internal loading. The amount of nutrients in the bottom sediment of the lake is extremely high. The sediments of degraded lakes are 
the main, inexhaustible source of biogenic compounds. Considering the content of the most important nutrient-phosphorus-in the particular parts of lake ecosystems, it was found that approximately $90 \%$ of the total phosphorus was contained in the upper 10-cm layer of the bottom sediments [13]. This result clearly indicates the need to limit this "source". The inhibition of internal loading is the main goal of all lake restoration methods, including artificial aeration, phosphorus inactivation, capping and the Ripl method [14-16].

The removal of bottom sediment is widely regarded as a radical but highly effective restoration method for shallow, heavily degraded reservoirs [17]. The complete removal of bottom sediment to the parent rock floor guarantees radical renovation of the lake and an increase in its volume, which often has previously been decreased due to the inflow of excessive pollution. Considering the thickness of sediments in postglacial lakes, often up to several meters or more, this method should be considered unrealistic.

Innovative lake restoration projects using the dredge method should be preceded by detailed monitoring of water and bottom sediment. Therefore, lake monitoring should be started with an examination of the spatial composition of bottom sediments to precisely determine the thickness of the most contaminated layer that is supposed to be removed. In addition, uncovered deposits that remain in the lake should be poor in nutrients, while phosphorus, as the main element responsible for eutrophication, must be stored in a biologically inactive form, i.e., as residual phosphorus or calcium-bound phosphorus [18-20]. This method of removing bottom deposits is very rarely used due to its complexity, cost and implementation difficulties. However, although the name of the method refers to bottom sediment removal, such a project must also take into account the output development and processing/utilization of the solid and liquid fractions [15,16,21]. The processing, management and utilization of deposits is often the greatest logistical and economic challenge.

An example of a very inept attempt at lake restoration by the bottom sediment removal method was the case of Mogileńskie Lake in Poland. The sediment and interstitial water removed from the lake were not properly managed, and before they were processed, the effluents returned to the lake water, destroying the initial effects and causing an ecological catastrophe [22].

In the case of the restoration of the Swedish Lake Trummen, the sediment was pumped to simple settling ponds constructed in an abandoned farming area from which the topsoil had first been removed. The runoff water from the settling ponds-a mixture of lake and interstitial water-was treated with aluminum sulfate in a simple plant for the precipitation of phosphate and suspended matter. Before restoration, the total phosphorus content of the lake water was approximately $600 \mu \mathrm{g} \mathrm{L}^{-1}$. The phosphorus concentration of the water from the settling ponds was on the order of milligrams per liter before the treatment. After precipitation, the total phosphorus content of the runoff water was approximately $30 \mu \mathrm{g} / \mathrm{L}$ [23]. The area designated for the infrastructure to process the liquid and solid output was approximately 30 ha. It should be noted that it is rare to find so much space in the vicinity of a lake that can be used to safely convert the removed deposit.

According to a study of the Vajgar artificial reservoir by Björk et al. [24], the top of the sediment that had accumulated in the pond served as an uncontrolled source of nutrients and was removed. The sediment pumping started in August 1991, and by the end of 1992, approximately 330,000 $\mathrm{m}^{3}$ of sediment had been pumped out of the pond and transported in pipes to seven settling lagoons approximately $2.5 \mathrm{~km}$ away, each of which was approximately 1 ha in area and $3-5 \mathrm{~m}$ deep. The sediment transported from the fish pond had a dry mass content of $10-15 \%$. The whole cost was approximately US $\$ 850,000$.

The above examples indicate that the removal of bottom sediments from reservoirs is logistically very difficult, and in the case of ill-considered solutions, it can cause the opposite effect-an ecological disaster. Another disadvantage of this method is the very high cost; therefore, before developing a project to extract sediments, the spatial distribution of the phosphorus in the sediment should be determined to accurately indicate the thickness of the sediment, the extraction of which will guarantee 
the improvement of the state of the lake as a result of stopping the emission of pollutants from the sediments back into the water column.

The aim of the study was to determine the spatial distribution of pollutants in bottom sediment and interstitial water of Karczemne Lake and on their basis to determine the thickness and volume of sediment necessary for extraction to improve the quality of water in the reservoir. This research has allowed the development of the concept of a completely new, safe and economically justified method of mining and managing the bottom sediments. The proposed method will prevent uncontrolled effluent drainage back into the lake basin. In addition, it does not require the construction of a completely new bottom sediment treatment system consisting of presses, centrifuges, polymer-dosing stations, water-conditioning equipment and reaction pools. After sediment is removed from the lake bowl, phosphorus inactivation and biomanipulation is also recommended.

\section{Material and Methods}

\subsection{Study Site}

Karczemne Lake ( $\left.54^{\circ} 19^{\prime} 42^{\prime \prime} \mathrm{N}, 18^{\circ} 11^{\prime} 27^{\prime \prime} \mathrm{E}\right)$ is a strongly degraded urban lake located in the Kaszubian Lake District and belongs to the macroregion of the Eastern Pomeranian District in Kartuzy town [25]. Karczemne Lake is a shallow, polymictic, flow-through lake. Its area is $40.4 \mathrm{ha}$, and its maximum depth is $2.3 \mathrm{~m}$ (Figure 1). More detailed morphometric parameters of the lake are given in Table 1.
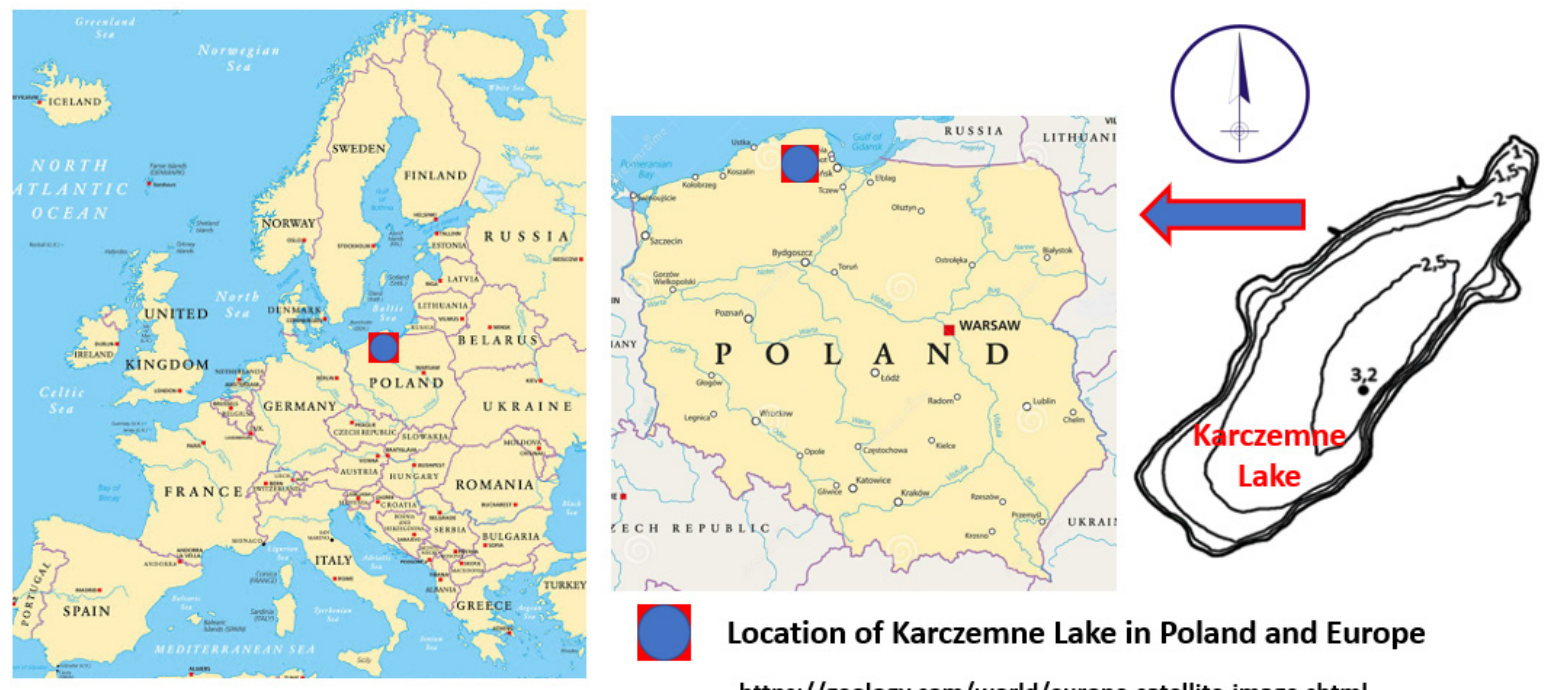

Location of Karczemne Lake in Poland and Europe

https://geology.com/world/europe-satellite-image.shtml

Figure 1. Location of the Karczemne Lake.

Table 1. Morphometric parameters of Karczemne Lake.

\begin{tabular}{cc}
\hline Parameter & Value \\
\hline Elevation of normal water table (m AMSL) & 203.7 \\
Lake surface (ha) & 40.4 \\
Maximum depth (m) & 3.2 \\
Average depth (m) & 1.98 \\
Relative depth & 0.0050 \\
Depth indicator & 0.62 \\
Volume (in thousand $\mathrm{m}^{3}$ ) & 798.3 \\
Maximum length (m) & 1282 \\
Maximum width (m) & 445 \\
Elongation indicator & 2.9 \\
Average width (m) & 315 \\
Shoreline length (m) & 3163 \\
Indicator of shoreline development & 1.4 \\
\hline
\end{tabular}


From the early 1950s, Karczemne Lake was transformed into a receiver for domestic sewage, as well as sewage from dairies, slaughterhouses, breweries, furniture factories and municipal hospitals. Over 30 years, $60 \%$ of the raw municipal sewage went to Karczemne Lake through six sanitary sewers. With the expansion of the urban area, the amount of municipal sewage increased. Impurities from emerging single-family housing were collected in leaking cesspits, which caused some of the pollution to seep into the ground and migrate toward the lake. Some cesspits had overflows to the combined sewerage network, and municipal sewage flowed directly to the lake in this way. It was also possible to illegally connect sanitary sewers from individual domestic properties to the stormwater drainage system and directly discharge sewage to the lake from homes located along the shore. The improvement of water and sewage management in Kartuzy City began in the mid-1970s. In 1982, a mechanical-biological sewage treatment plant was opened. In the 1990s, almost the entire city was connected to a sanitary sewerage system, and it was only in 2010 that the management of stormwater began to be organized through the construction of settling tanks and stormwater separators. Until 2018, the stormwater drainage network in Kartuzy covered only part of the city-17\%. This situation meant that during heavy rainfall, local flooding occurred, and the excess rainwater and snowmelt from streets that did not have a rainwater drainage system penetrated the sanitary sewer system, overloading it. The connection of the existing stormwater drainage system to the sanitary sewer system caused raw sewage to load into the lake.

The total catchment basin of Karczemne Lake covers $5.15 \mathrm{~km}^{2}$. This area is covered by two entirely different (in their ability to activate the load of nutrients in a surface flow) forms of land use: forests $(57 \%)$ and urbanized areas (43\%). The direct catchment of Karczemne Lake, excluding the area covered by the drainage system collecting rainwater, covers $0.45 \mathrm{~km}^{2}$ : wasteland constitutes $20.7 \%$ of its total surface area, and forests grow over the other $79.3 \%$. The calculations of the amount of nutrients that are annually brought to the lake with a watercourse or from outfalls were performed based on their actual concentration in water (total phosphorus-TP and total nitrogen-TN) and flows measured at the individual stations during yearly field studies. The partial load for a given day was the product of the volume of water (momentary flow) and the concentration of given nutrients in the water. Nutrient loads were calculated with a generally accepted method of time periods. The magnitude of a lake load with nutrients originating from surface flows from the direct catchment was calculated with a method that is recommended and applied by the OECD (Organisation for Economic Cooperation and Development) that involves the use of flow coefficients. The load of nutrients introduced to a lake with precipitation was determined based on the coefficients of pollution deposition per surface unit. It was assumed that angling baits are the main sources of pollution resulting from the recreational use of lakes. Based on the data obtained from Group No 57 of the Polish Angling Association from Kartuzy and conversion factors described by Wołos and Mioduszewska [26], the average number of anglers who used baits was calculated for each of the lakes. It was also assumed that the average content of biogenic compounds in fish feed was $3.0 \mathrm{~g} \mathrm{P}$ and $12.0 \mathrm{~g} \mathrm{~N}$ per $\mathrm{kg}$ of bait.

Until the end of 2018, Karczemne Lake was a receiver of nutrient loads from both the catchment and atmosphere, which involved the following basic components: areal sources; inflow of waters via a watercourse that links Karczemne Lake with Mielenko Lake (this watercourse flows into the reservoir in the central part of the west bank); point sources (6 stormwater outfalls and sometimes the illegal discharge of municipal sewage); atmospheric sources and recreation, such as angling. The total loads of phosphorus and nitrogen introduced into Karczemne Lake were $134.7 \mathrm{~kg} \mathrm{P}_{\text {year }}{ }^{-1}\left(0.330 \mathrm{~g} \mathrm{P} \mathrm{m}^{-2}\right.$ year $^{-1}$ ) and $1133.8 \mathrm{~kg} \mathrm{~N}_{\text {year }}{ }^{-1}\left(2.80 \mathrm{~g} \mathrm{~N} \mathrm{~m}^{-2}\right.$ year $\left.^{-1}\right)$, respectively. The permissible and dangerous (critical) loads calculated for this lake from Vollenweider's hydrological model [27] were $0.030 \mathrm{~g} \mathrm{P} \mathrm{m}^{-2}$ year (12.1 $\mathrm{kg}$ year $^{-1}$ ) and $0.060 \mathrm{~g} \mathrm{P} \mathrm{m}^{-2}$ year $\left(24.2 \mathrm{~kg} \mathrm{year}^{-1}\right)$, respectively. The analysis revealed that the total phosphorus load introduced from external sources to the lake exceeded the dangerous load and was responsible for accelerated eutrophication. The phosphorus load introduced to Karczemne Lake was $550 \%$ higher than the critical load. 


\subsection{Water Sample Collection and Analysis}

The physicochemical properties of water samples from Karczemne Lake were determined over an annual cycle (April 2018, June 2018, August 2018 and November 2018). Samples were taken at the point of the maximum depth (Figure 2). The scope of the water analysis included the total phosphorus (TP; standard methods 2012), total nitrogen (TN; Shimadzu TOC 5000 analyzer, Kyoto, Japan), chlorophyll a by the colorimetric method (after concentration on a glass fiber filter Whatman GF/B and extraction with acetone-Nanocolor UV/vis, Macherey-Nagel (GmbH \& Co., KG, Frankfurt, Germany); 750/664 $\mathrm{nm}$ before and 750/665 $\mathrm{nm}$ after acidification) and visibility (Secchi disc).

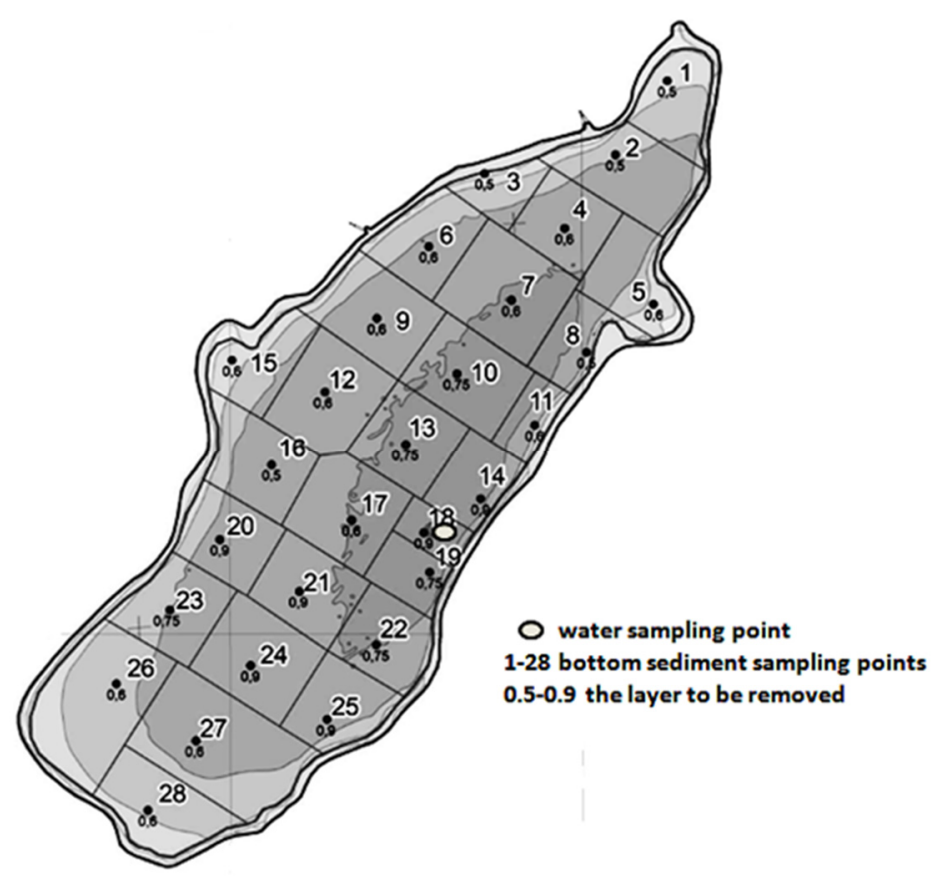

Figure 2. The spatial distribution of research points with the thickness of the sediment layer meant to mining.

The trophic state index (TSI) was calculated based on the concentrations of total phosphorus, total nitrogen and chlorophyll a, as well as Secchi disc visibility [28,29].

The coefficient of variation (CV) for the repeated analysis was $2 \%$ [30].

\subsection{Bottom Sediment Collection}

The bottom sediment sampling was carried out on 7, 8, 9 and 11 March 2018. Samples for analysis were taken at 28 research stations (Figure 2), for which geographical coordinates were determined (Table 2).

The sediment cores were obtained using a Kajak tube sampler (KC Company, Silkeborg, Denmark). Every core length included the sediment layer down to the parent rock (floor). In this way, the thickness of the retrieved sediments was determined precisely at individual sites, and their organoleptic properties were assessed. During the collection, individual cores were divided into layers with a thickness of $30 \mathrm{~cm}(\mathrm{a}-0-30 \mathrm{~cm}, \mathrm{~b}-31-60 \mathrm{~cm}, \mathrm{c}-61-90 \mathrm{~cm}, \mathrm{~d}-91-120 \mathrm{~cm}, \mathrm{e}-121-150 \mathrm{~cm}$ and $\mathrm{f}-151-180 \mathrm{~cm})$ and prepared as separate samples. A total of 112 material samples were collected from the bottom of the lake. 
Table 2. Geographical coordinates of sediment sampling points from Karczemne Lake.

\begin{tabular}{|c|c|c|}
\hline Point Number & Latitude & Longitude \\
\hline 1 & $\mathrm{~N}: 54^{\circ} 33^{\prime} 27.5^{\prime \prime}$ & E: $18^{\circ} 19^{\prime} 61.4^{\prime \prime}$ \\
\hline 2 & $\mathrm{~N}: 54^{\circ} 33^{\prime} 19.0^{\prime \prime}$ & $\mathrm{E}: 18^{\circ} 19^{\prime} 51.1^{\prime \prime}$ \\
\hline 3 & $\mathrm{~N}: 54^{\circ} 33^{\prime} 16.9^{\prime \prime}$ & $\mathrm{E}: 18^{\circ} 19^{\prime} 25.3^{\prime \prime}$ \\
\hline 4 & $\mathrm{~N}: 54^{\circ} 33^{\prime} 10.6^{\prime \prime}$ & $\mathrm{E}: 18^{\circ} 19^{\prime} 41.0^{\prime \prime}$ \\
\hline 5 & $\mathrm{~N}: 54^{\circ} 33^{\prime} 01.8^{\prime \prime}$ & $\mathrm{E}: 18^{\circ} 19^{\prime} 58.5^{\prime \prime}$ \\
\hline 6 & $\mathrm{~N}: 54^{\circ} 33^{\prime} 08.5^{\prime \prime}$ & $\mathrm{E}: 18^{\circ} 19^{\prime} 14.3^{\prime \prime}$ \\
\hline 7 & $\mathrm{~N}: 54^{\circ} 33^{\prime} 02.3^{\prime \prime}$ & $\mathrm{E}: 18^{\circ} 19^{\prime} 30.5^{\prime \prime}$ \\
\hline 8 & $\mathrm{~N}: 54^{\circ} 32^{\prime} 96.3^{\prime \prime}$ & $\mathrm{E}: 18^{\circ} 19^{\prime} 45.3^{\prime \prime}$ \\
\hline 9 & $\mathrm{~N}: 54^{\circ} 33^{\prime} 00.3^{\prime \prime}$ & $\mathrm{E}: 18^{\circ} 19^{\prime} 04.0^{\prime \prime}$ \\
\hline 10 & $\mathrm{~N}: 54^{\circ} 32^{\prime} 93.9^{\prime \prime}$ & $\mathrm{E}: 18^{\circ} 19^{\prime} 19.7^{\prime \prime}$ \\
\hline 11 & $\mathrm{~N}: 54^{\circ} 32^{\prime} 87.9^{\prime \prime}$ & $\mathrm{E}: 18^{\circ} 19^{\prime} 35.0^{\prime \prime}$ \\
\hline 12 & $\mathrm{~N}: 54^{\circ} 32^{\prime} 91.8^{\prime \prime}$ & $\mathrm{E}: 18^{\circ} 18^{\prime} 93.8^{\prime \prime}$ \\
\hline 13 & $\mathrm{~N}: 54^{\circ} 32^{\prime} 85.7^{\prime \prime}$ & $\mathrm{E}: 18^{\circ} 19^{\prime} 09.6^{\prime \prime}$ \\
\hline 14 & $\mathrm{~N}: 54^{\circ} 32^{\prime} 79.4^{\prime \prime}$ & $\mathrm{E}: 18^{\circ} 19^{\prime} 24.3^{\prime \prime}$ \\
\hline 15 & $\mathrm{~N}: 54^{\circ} 32^{\prime} 95.5^{\prime \prime}$ & $\mathrm{E}: 18^{\circ} 18^{\prime} 75.4^{\prime \prime}$ \\
\hline 16 & $\mathrm{~N}: 54^{\circ} 32^{\prime} 83.4^{\prime \prime}$ & $\mathrm{E}: 18^{\circ} 18^{\prime} 83.2^{\prime \prime}$ \\
\hline 17 & $\mathrm{~N}: 54^{\circ} 32^{\prime} 77.0^{\prime \prime}$ & $\mathrm{E}: 18^{\circ} 18^{\prime} 98.9^{\prime \prime}$ \\
\hline 18 & $\mathrm{~N}: 54^{\circ} 32^{\prime} 75.5^{\prime \prime}$ & $\mathrm{E}: 18^{\circ} 19^{\prime} 13.1^{\prime \prime}$ \\
\hline 19 & $\mathrm{~N}: 54^{\circ} 32^{\prime} 71.0^{\prime \prime}$ & $\mathrm{E}: 18^{\circ} 19^{\prime} 14.3^{\prime \prime}$ \\
\hline 20 & $\mathrm{~N}: 54^{\circ} 32^{\prime} 74.8^{\prime \prime}$ & $\mathrm{E}: 18^{\circ} 18^{\prime} 72.9^{\prime \prime}$ \\
\hline 21 & $\mathrm{~N}: 54^{\circ} 32^{\prime} 68.8^{\prime \prime}$ & $\mathrm{E}: 18^{\circ} 18^{\prime} 88.6^{\prime \prime}$ \\
\hline 22 & $\mathrm{~N}: 54^{\circ} 32^{\prime} 62.6^{\prime \prime}$ & $\mathrm{E}: 18^{\circ} 19^{\prime} 03.7^{\prime \prime}$ \\
\hline 23 & $\mathrm{~N}: 54^{\circ} 32^{\prime} 66.7^{\prime \prime}$ & $\mathrm{E}: 18^{\circ} 18^{\prime} 63.1^{\prime \prime}$ \\
\hline 24 & $\mathrm{~N}: 54^{\circ} 32^{\prime} 60.3^{\prime \prime}$ & $\mathrm{E}: 18^{\circ} 18^{\prime} 78.9^{\prime \prime}$ \\
\hline 25 & $\mathrm{~N}: 54^{\circ} 32^{\prime} 54.1^{\prime \prime}$ & $\mathrm{E}: 18^{\circ} 18^{\prime} 94.0^{\prime \prime}$ \\
\hline 26 & $\mathrm{~N}: 54^{\circ} 32^{\prime} 58.2^{\prime \prime}$ & $\mathrm{E}: 18^{\circ} 18^{\prime} 52.5^{\prime \prime}$ \\
\hline 27 & $\mathrm{~N}: 54^{\circ} 32^{\prime} 51.7^{\prime \prime}$ & $\mathrm{E}: 18^{\circ} 18^{\prime} 68.2^{\prime \prime}$ \\
\hline 28 & $\mathrm{~N}: 54^{\circ} 32^{\prime} 43.7^{\prime \prime}$ & $\mathrm{E}: 18^{\circ} 18^{\prime} 58.6^{\prime \prime}$ \\
\hline
\end{tabular}

\subsection{Bottom Sediment and Interstitial Water Sample Analysis}

The output, after being transported to the laboratory, was weighed to determine the volumes and densities of the fresh samples. The samples were then dried to constant weight, and the volume and density were redetermined. The interstitial water was obtained from the sediment by centrifugation at $3000 \mathrm{rpm}$ for 20 min according to Brzozowska and Gawrońska [31].

In the interstitial water samples, ammonia was examined by ionic chromatography using an ICS-5000 DIONEX DC, TKN by IL 550 TOC-TN analyzer, Hach Inc. (Larimer Country, CO, USA), phosphates and total $\mathrm{P}$ were measured by a Nano color spectrophotometer, and organic $\mathrm{P}$ was calculated as the difference between the TP and phosphate amounts. In the investigated sediments, organic matter was measured by LOI (the percent weight loss during the ignition) using weight analysis [31], total nitrogen was measured by the Kjeldahl method and silica was measured using weight analysis after preliminary digestion of the sediment sample in a mixture of strong mineral acids $\left(\mathrm{H}_{2} \mathrm{SO}_{4}, \mathrm{HClO}_{4}\right.$ and $\mathrm{HNO}_{3}$ 1:2:3) and filtering through a No. 390 filter. The phosphorus fractions were analyzed by sequential extraction according to the Rydin and Welch method [32] modified by van Hullebush et al. [33]. In the analyzed sediments, samples were examined for the following:

- $\quad$ Labile phosphorus $\left(\mathrm{NH}_{4} \mathrm{Cl}-\mathrm{P}\right.$; after $2 \times 2 \mathrm{~h}$ extraction in $\left.1 \mathrm{M} \mathrm{NH}_{4} \mathrm{Cl}\right)$,

- Phosphorus sensitive for redox potential changes (BD-P; after $2 \mathrm{~h}$ extraction in $0.11 \mathrm{M}$ buffered dithionite solution),

- Phosphorus bound with aluminum and organic matter (NaOH-TP; after $16 \mathrm{~h}$ extraction in $0.1 \mathrm{M}$ $\mathrm{NaOH}$ and mineralization of extract using the $10 \mathrm{~N}$ mixture of $\mathrm{H}_{2} \mathrm{SO}_{4}$ and $\mathrm{HClO}_{4}$ ),

- Phosphorus bound with aluminum and iron oxides and hydroxides ( $\mathrm{NaOH}-\mathrm{rP}$; directly in the $\mathrm{NaOH}$ extract), 
- Phosphorus bound with organic matter (NaOH-nrP; was calculated as the difference between $\mathrm{NaOH}-\mathrm{TP}$ and $\mathrm{NaOH}-\mathrm{rP})$,

- Calcium bound phosphorus (HCl-P; after $16 \mathrm{~h}$ extraction in $0.5 \mathrm{M} \mathrm{HCl}$ ),

- Residual phosphorus (res-P; was calculated as the difference between TP after mineralization using a mixture of $\mathrm{H}_{2} \mathrm{SO}_{4}$ and $\mathrm{HClO}_{4}$ and the sum of the fractions of $\mathrm{NH}_{4} \mathrm{Cl}-\mathrm{P}, \mathrm{BD}-\mathrm{P}, \mathrm{NaOH}-\mathrm{TP}$ and $\mathrm{HCl}-\mathrm{P})$.

Extracted phosphorus was determined using the molybdate blue method according to Hermanowicz et al. [34]. The results were statistically analyzed (basic statistics-mean values, standard deviation) using a Statistica 13.0 software package [35].

\subsection{Studies of the Spatial Variability of Phosphorus and Nitrogen Concentrations in the Bottom Sediment}

Lake restoration using the dredge method must be planned very precisely. The most important element of the project is to precisely define the thickness of the deposits that should be removed from the ecosystem. The thickness needed to remove the deposits is determined on the basis of the changes in phosphorus content in the sediment and the fractions in which phosphorus is present. The analysis of the Karczemne Lake bottom was planned in such a way to obtain the most complete information about the structure of its bottom. Due to the lack of data regarding the thickness and properties of the bottom sediments, probes were planned at points evenly distributed over the whole bottom surface of the lake. This methodical approach is recommended by the EPA [36] in situations with limited preliminary data. The results of the soundings referred to the partial surfaces of the lake bottom for which the given probing point was the geometric center (Voronoi diagrams; Wolfram Math Worlds [37]).

\subsection{Studies of Heavy Metals and Persistent Organic Pollutant Contents}

In accordance with the guidelines included in the Ordinance of Ministry of the Environment (OME) [38] on waste recovery outside installations and equipment, six aggregate samples were prepared for analyzing the content of stable organic pollutants (POPs), polycyclic aromatic hydrocarbons (PAHs) and heavy metals in the sediments.

No. 1-mixed sediment sample taken from stations 1-15, layers a $(0-30 \mathrm{~cm})$ and $\mathrm{b}(31-60 \mathrm{~cm})$;

No. 2-mixed sediment sample taken from stations 1-15, layers c $(61-90 \mathrm{~cm})$ and d $(91-120 \mathrm{~cm})$;

No. 3-mixed sediment sample taken from stations 16-28, layers a $(0-30 \mathrm{~cm})$ and b $(31-60 \mathrm{~cm})$;

No. 4-mixed sediment sample taken from stations 16-28, layers c $(61-90 \mathrm{~cm})$ and d $(91-120 \mathrm{~cm})$;

No. 5-mixed sediment sample taken from station 5, layers a $(0-30 \mathrm{~cm})$ and b $(31-60 \mathrm{~cm})$;

No. 6-mixed sediment sample taken from station 5, layers c $(61-90 \mathrm{~cm})$ and d $(91-120 \mathrm{~cm})$.

Limitations on the further use of bottom sediments or other types for development can result from higher than normal heavy metal content according to Hermanowicz et al. [34] or the presence of extremely hazardous persistent organic pollutants (POPs), such as hexachlorobenzene (HCB), polychlorinated biphenyls (PCBs) and polycyclic aromatic hydrocarbons (PAHs). Analyses of heavy metals, polycyclic aromatic hydrocarbons and polychlorinated biphenyls were performed by the AAS (Atomic Absorption Spectrometer), ICP-AES (Inductively Coupled Plasma-Atomic Emission Spectrometer) and GC MS (Gas Chromatography Mass Spectrometry) methods. The coefficient of variation $(\mathrm{CV})$ for the repeated analysis was $2 \%$ [30].

The usefulness of deposits for development was verified based on The Act on Waste [39] and concentrations of toxic substances caused by pollution [39]. The waste catalog classifies bottom sediments as waste with code 170505 (dredging spoil containing or contaminated with dangerous substances), with the note that the sediments are hazardous waste or 170506 (dredging spoil other than those mentioned in 1705 05). 


\section{Results}

\subsection{Trophic Status}

The value of every index calculated from the concentrations of total phosphorus, total nitrogen, visibility and chlorophyll a exceeded TSI 70 (Figure 3). This demonstrated strong pollution of the analyzed lake.

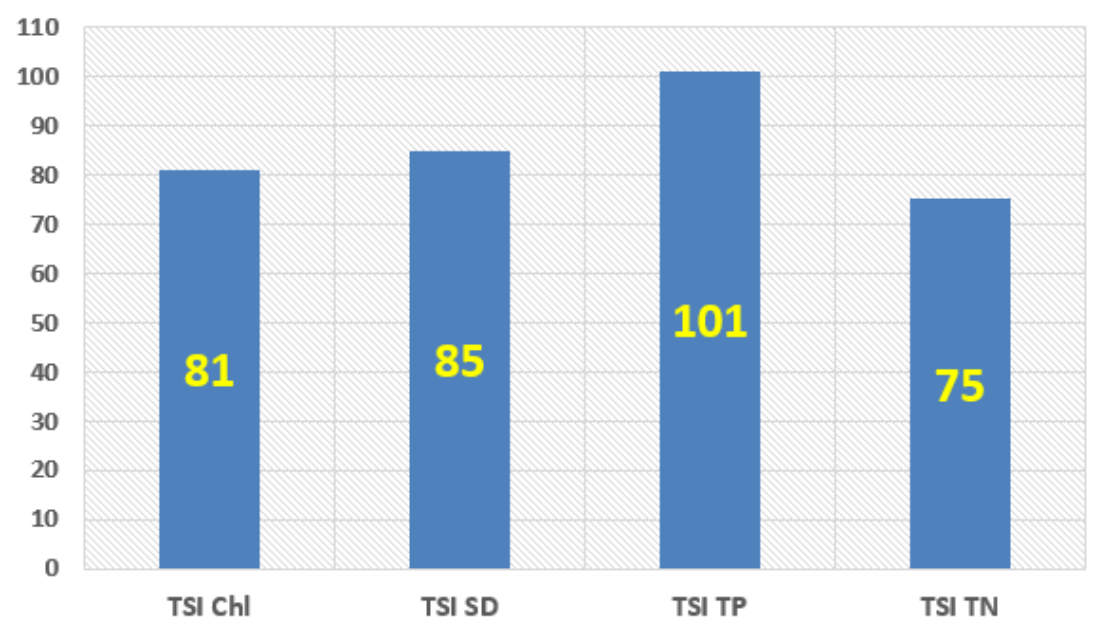

TSI: oligotrophy<40; mezotrophy 40-50; eutrophy 50-70; hypertrophy>70

Figure 3. The trophic status index (TSI) calculated on the basis of visibility (SD) chlorophyll concentrations (Chl), total phosphorus (TP) and total nitrogen (TN).

\subsection{Phosphorus and Nitrogen Content in the Interstitial Water of Karczemne Lake}

The interstitial water of Karczemne Lake was rich in biogenic compounds. The mean content of total phosphorus varied between 0.61 and $10.0 \mathrm{mg} \mathrm{P} \mathrm{L}^{-1}$ (Figure 4).

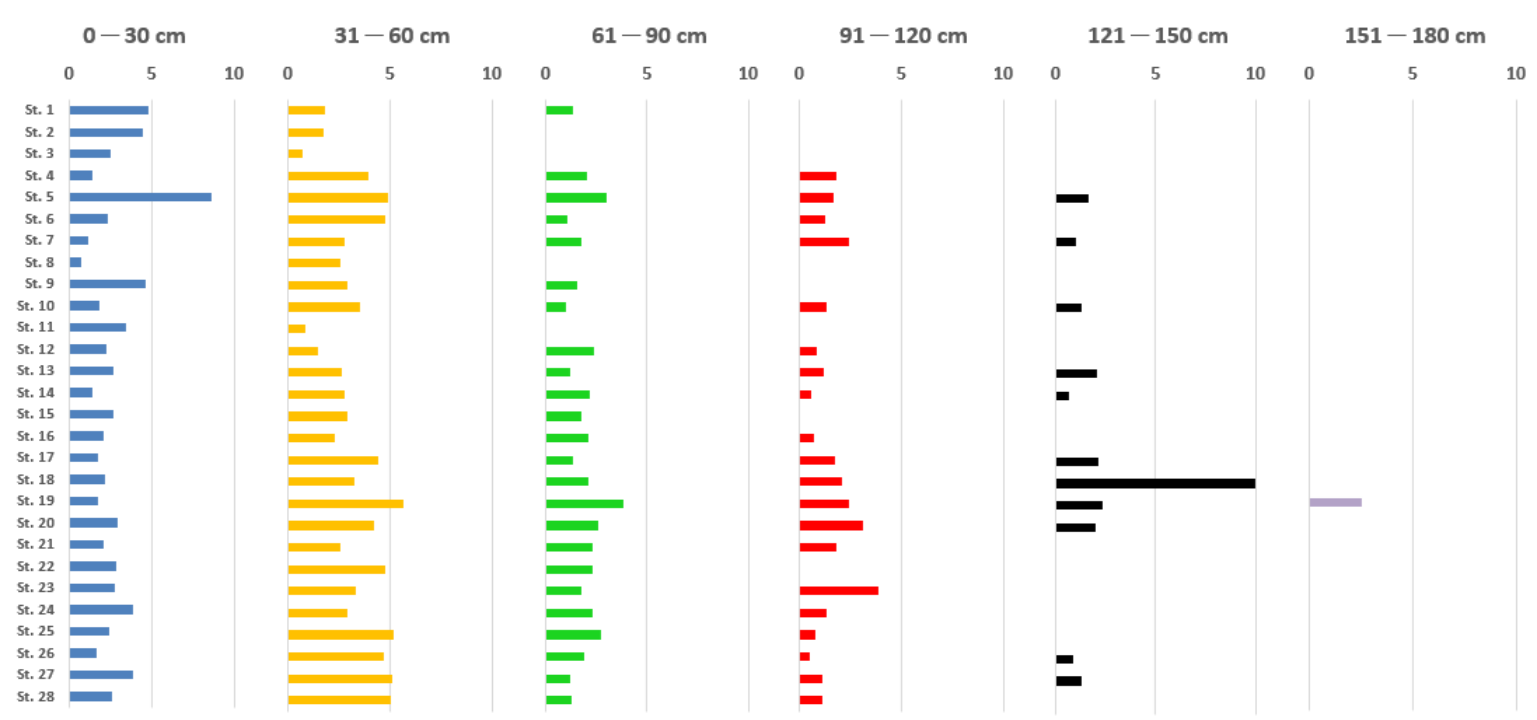

Figure 4. Mean content of total phosphorus in the interstitial water of Karczemne Lake (mg P L $\left.{ }^{-1}\right)$.

In the composition of total phosphorus in the interstitial water of the deeper sediment layers, organic phosphorus predominated, while in the layer with a thickness of $30 \mathrm{~cm}$, phosphates prevailed. The highest concentration of phosphorus was recorded in the interstitial water separated from the bottom sediment that was under the influence of anthropopression, i.e., near the outlet of stormwater 
collectors that previously experienced the inflow of domestic and industrial sewage. Sewage discharge points were located along the eastern shore of the lake. There, the maximum concentration of total phosphorus usually occurred in the interstitial water of the b layer: $31-60 \mathrm{~cm}$.

The mean total nitrogen content in the interstitial water of Karczemne Lake varied from 9.60 to $71.40 \mathrm{mg} \mathrm{N} \mathrm{L}^{-1}$ (Figure 5). The concentrations of TN in the interstitial water clearly increased with depth in the sediment. In the nitrogen structure, the organic form was predominant. In the analyzed water, mineral nitrogen was in the form of ammonium nitrogen, the amount of which varied between 4.00 (St. 2 a) and $37.80 \mathrm{mg} \mathrm{N} \mathrm{L}^{-1}$ (St. 27 e). The values of ammonium nitrogen increased in the interstitial water in the sediment. The highest ammonia contents were found in the interstitial water of the bottom sediment located in the area bounded by $2 \mathrm{~m}$ and $3 \mathrm{~m}$ isobaths and at probing point No. 5 .

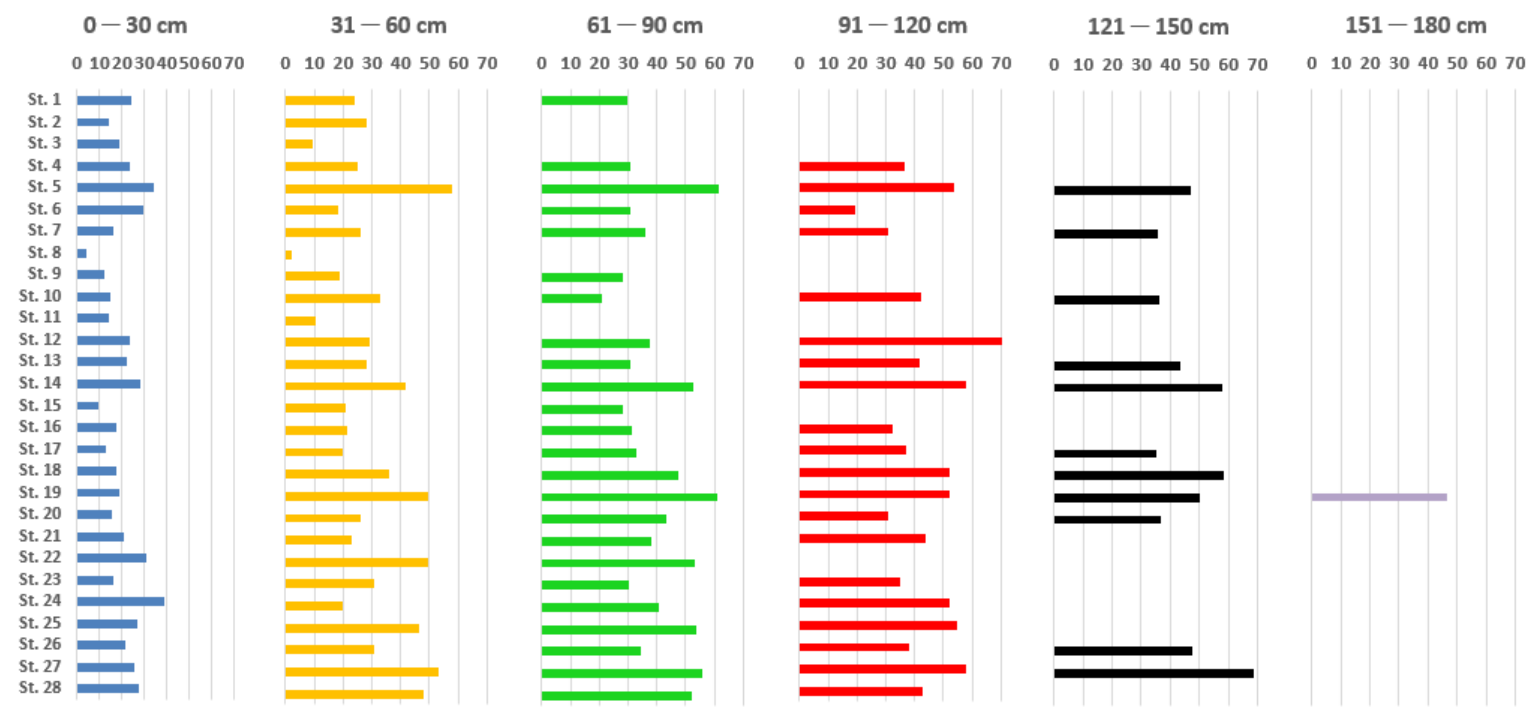

Figure 5. Mean content of total nitrogen in the interstitial water of Karczemne Lake $\left(\mathrm{mg} \mathrm{N} \mathrm{L}^{-1}\right)$.

\subsection{Density and Hydration of the Analyzed Bottom Sediment}

Spatially, the bottom sediments of Karczemne Lake were characterized by a heterogeneous structure and variations in thickness and degree of consolidation.

The maximum thickness of modern sediments was $1.8 \mathrm{~m}$. The thickness of the deposit is related to the long-term supply of sewage, which results in clear shallowing of the lake bed. Littoral deposits were characterized by the smallest thicknesses, with an average of $60 \mathrm{~cm}$.

The deposits with the largest thickness occurred in the region of the maximum depth of the lake and in the places of inflow of municipal and industrial sewage.

The bottom sediments of Karczemne Lake had a loose structure that was susceptible to resuspension (agitation). The sediment mean hydration in the $30 \mathrm{~cm}$ thick layer a fluctuated from approximately 94-95\% (Figure 6).

More dense and compact structures were observed only in the lower layers of the cores, especially in the littoral zone (Figure 7). The boundaries of structures within the cores were not clearly marked. The floor layer, constituting the native soil, was gyttja, i.e., organic and mineral sediment comprised mainly of the remains of allochthonous organisms with an admixture of sands. The mean density of the deposits of Karczemne Lake ranged from 0.99 to $1.45 \mathrm{~g} \mathrm{~cm}^{-3}$, and on average, it was $1.05 \mathrm{~g} \mathrm{~cm}^{-3}$ (Figure 7). 


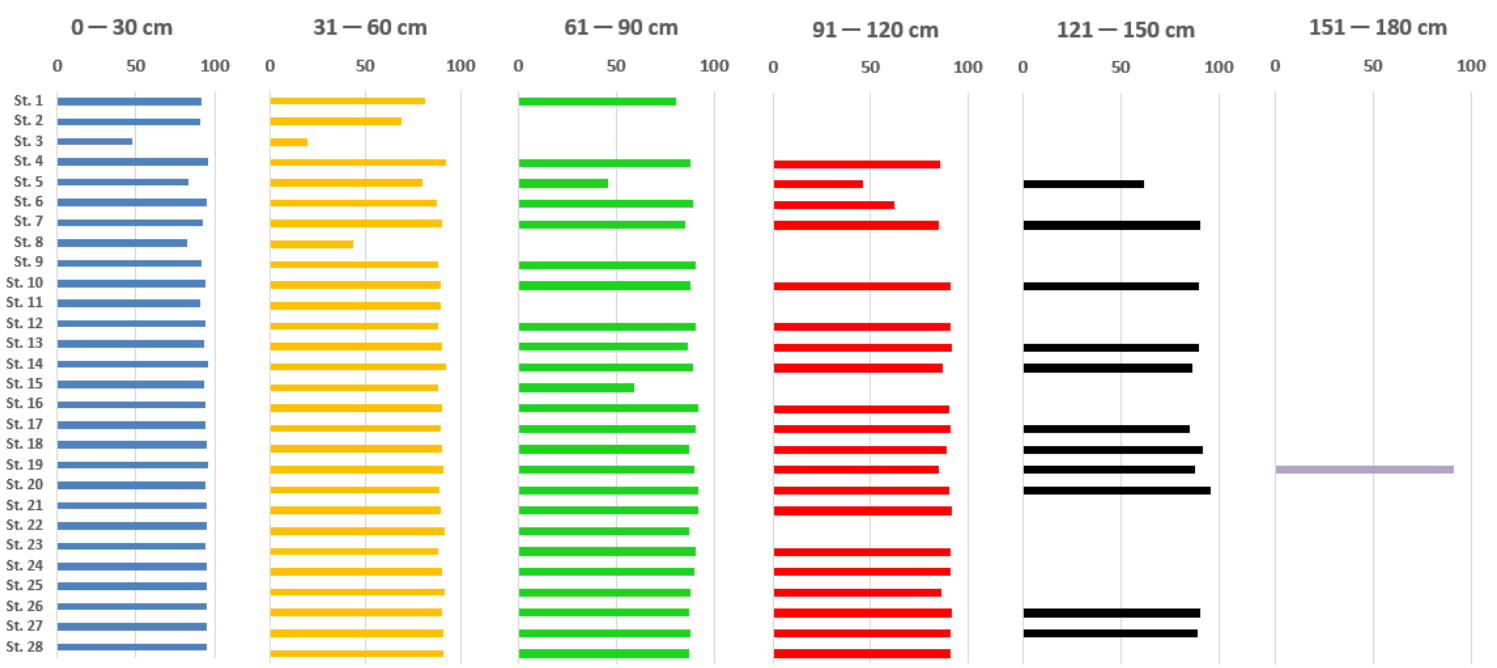

Figure 6. Mean hydration of the bottom sediment of Karczemne Lake (\%).
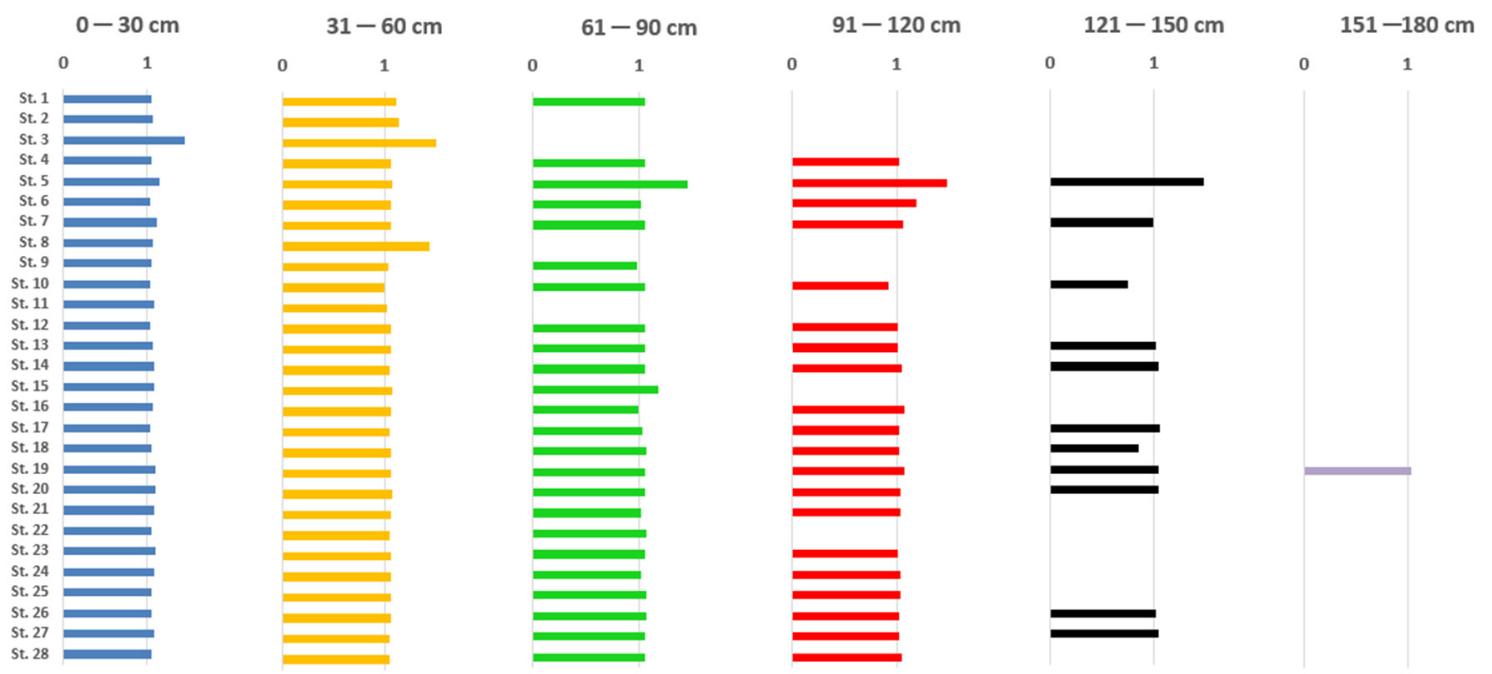

Figure 7. Mean density of the bottom sediment of Karczemne Lake $\left(\mathrm{g} \mathrm{cm}^{-3}\right)$.

\subsection{Chemical Composition of Bottom Sediment of Karczemne Lake}

The average chemical composition of the bottom sediments of Karczemne Lake was quite variable. The sediments that accumulated in the central part of the basin, up to a depth of $60 \mathrm{~cm}$, can be considered mixed according to the Stangenberg nomenclature [40] because none of the components was present in amounts exceeding 50\% of the dry mass. The organic matter in these sediments ranged from $15.8 \%$ to $43.5 \%$ of the dry mass. In the coastal regions of the lake and in deeper levels of sediment from the central part of the reservoir, the dominant component was silica, accounting for up to $92 \%$ of the dry mass. These bottom deposits can be described as silicate. The amounts of nitrogen in the analyzed sediments varied from $0.20 \%$ to $2.50 \% \mathrm{~N}$ dry weight (Figure $8 \mathrm{a}-\mathrm{d}$ ). Lower concentrations of nitrogen were found in the northern part of the lake along the axis determined by the inflow of the Klasztorna Struga (sounding stations 1-8). In the rest of the reservoir, the bottom deposits were richer in nitrogen, especially in the areas of the maximum depth of the basin.

The main components of the sorption complex of the bottom sediments of Karczemne Lake were iron (approximately 3.5\% d.w.) and aluminum (approximately 3.0\% d.w.). The combination of phosphorus and iron is unstable due to the variable valence of iron. Under anaerobic conditions, iron turns into a reduced form, releasing phosphates into the water. The bottom sediment of Karczemne Lake contained very high amounts of phosphorus, ranging from $0.1 \%$ to $7.3 \%$ of the dry mass (Figure $8 \mathrm{a}-\mathrm{d}$ ). 
Maximum amounts were found in the layer of deposits with a thickness of $60 \mathrm{~cm}$ and, at some points, up to $90 \mathrm{~cm}$. Below $90 \mathrm{~cm}$, much lower values were observed (Figure $8 \mathrm{a}-\mathrm{d}$ ).

The mean concentrations of total phosphorus in the bottom sediments of Karczemne Lake were very high. To date, no other lake in Poland has recorded such high values of phosphorus. The maximum amount of total phosphorus was found at research point number 5: $31.856 \mathrm{mg} \mathrm{P} \mathrm{g}^{-1}$ d.w. in the surface sediments of layer a $(0-30 \mathrm{~cm})$. Phosphorus amounts exceeding $10 \mathrm{mg} \mathrm{P} \mathrm{g}^{-1} \mathrm{~d}$.w. were found at the following research points: $1 \mathrm{a}\left(14.1 \mathrm{mg} \mathrm{P} \mathrm{g}^{-1}\right.$ d.w.), $10 \mathrm{a}\left(11.2 \mathrm{mg} \mathrm{P} \mathrm{g}^{-1}\right.$ d.w.), $14 \mathrm{a}\left(10.4 \mathrm{mg} \mathrm{P} \mathrm{g}^{-1}\right.$ d.w. $)$, $14 \mathrm{~b}$ (14.4 $\mathrm{mg} \mathrm{P} \mathrm{g}^{-1}$ d.w.), 15 a (22.9 $\mathrm{mg} \mathrm{P} \mathrm{g}^{-1}$ d.w.), 16 a (16.9 $\mathrm{mg} \mathrm{P} \mathrm{g}^{-1}$ d.w.), 24 b (12.9 $\mathrm{mg} \mathrm{P} \mathrm{g}^{-1}$ d.w.), 26 a, b (12.0 $\mathrm{mg} \mathrm{P} \mathrm{g}^{-1}$ d.w.), 28 a (13.6 $\mathrm{mg} \mathrm{P} \mathrm{g}^{-1}$ d.w.) and 28 b (16.6 $\mathrm{mg} \mathrm{P} \mathrm{g}^{-1}$ d.w.; Figure 8a-d).

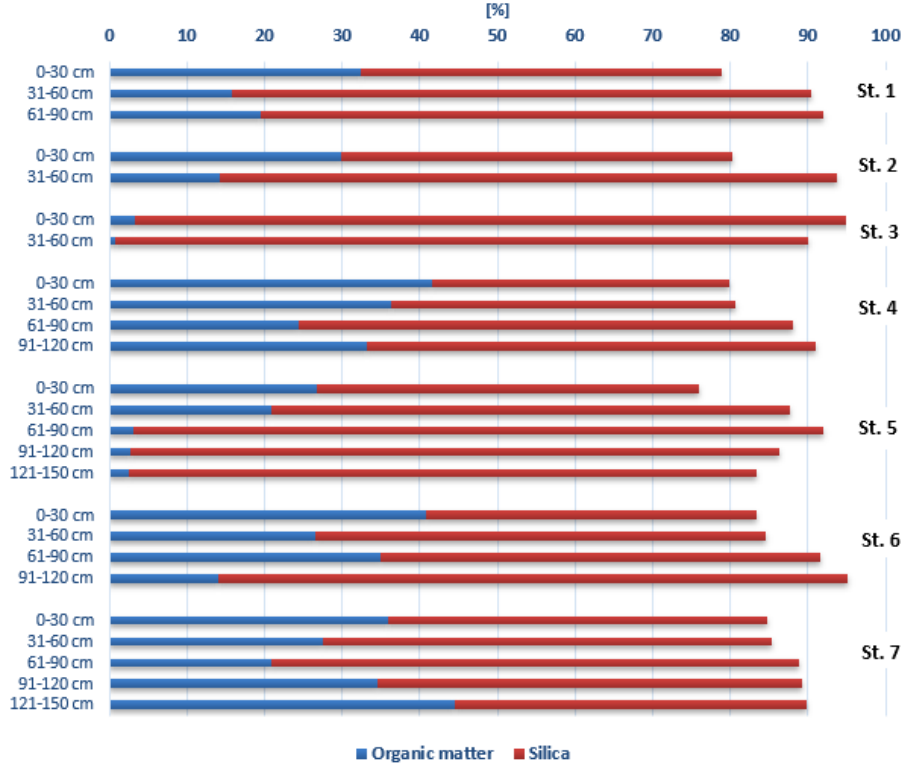

(a)

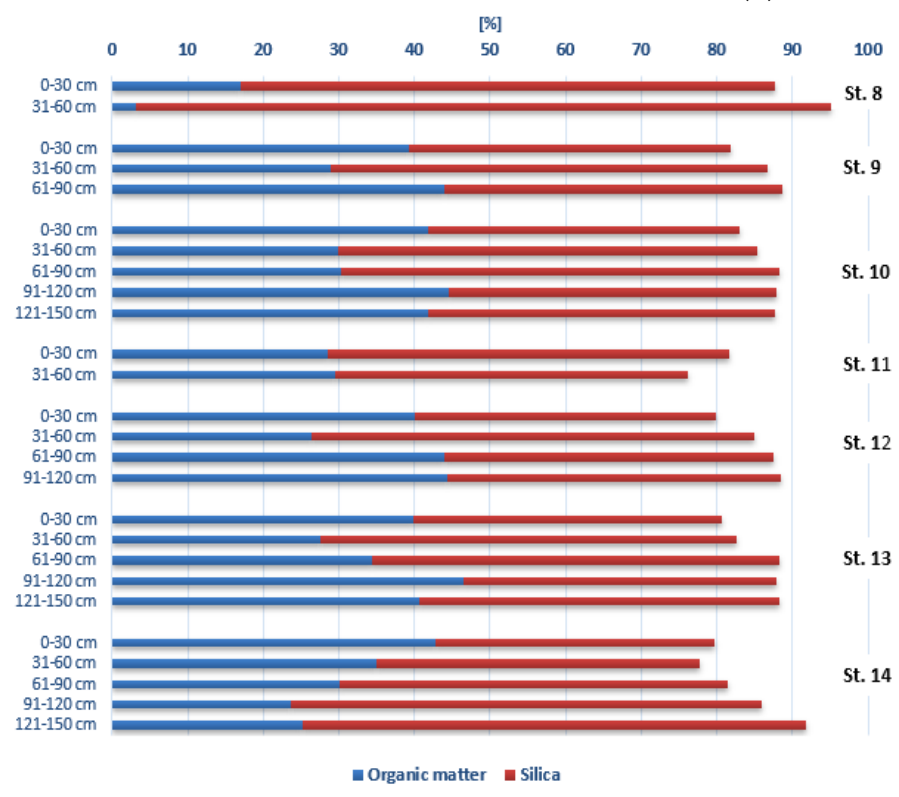

(b)
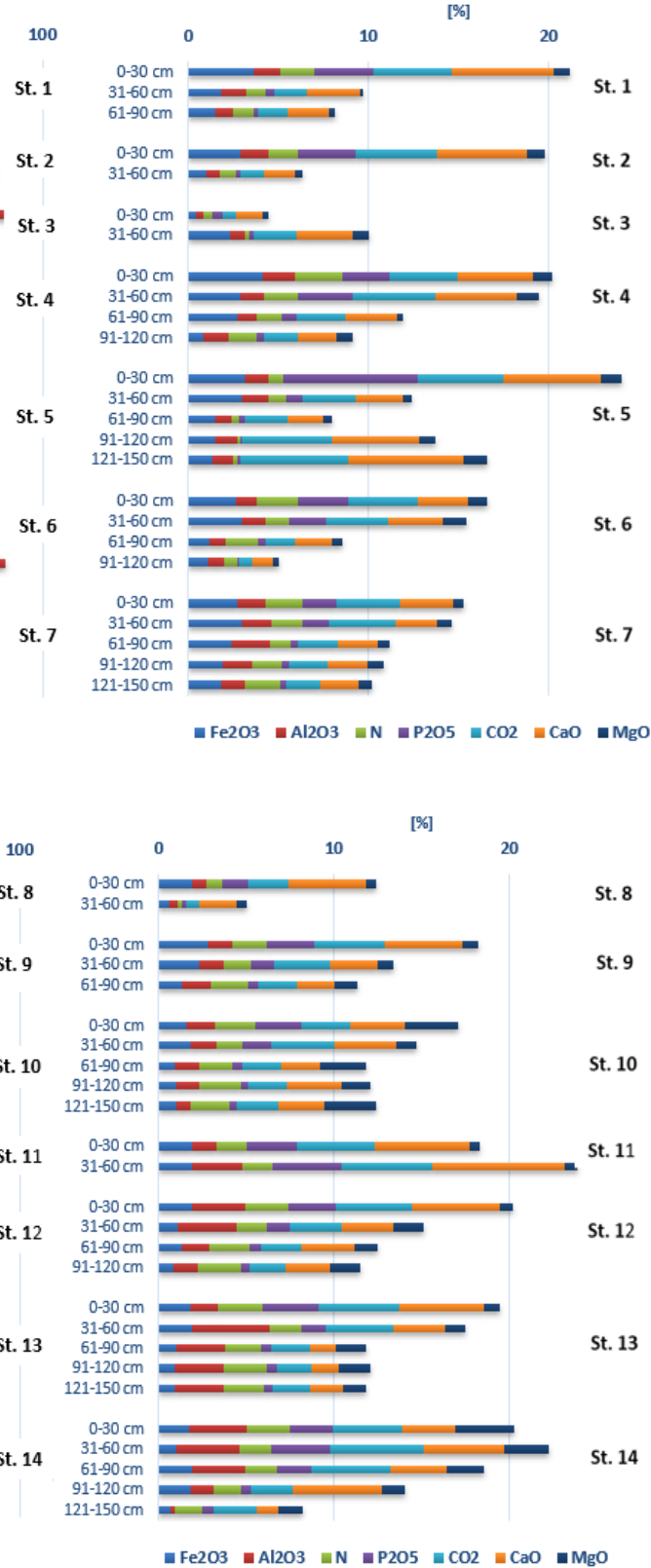

Figure 8. Cont. 


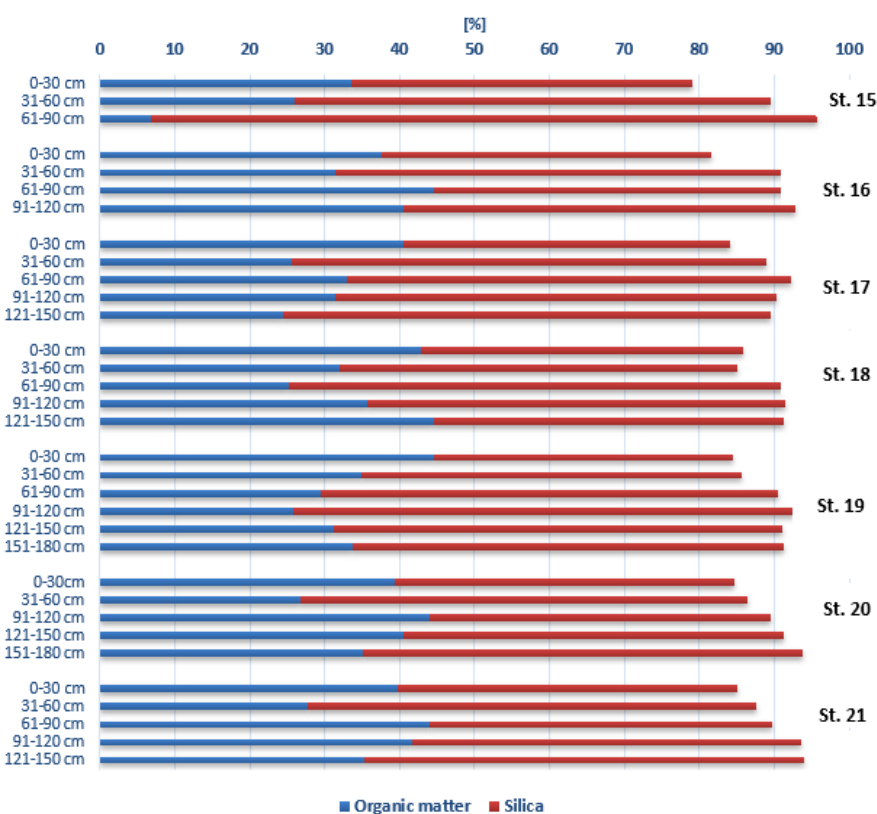

(c)

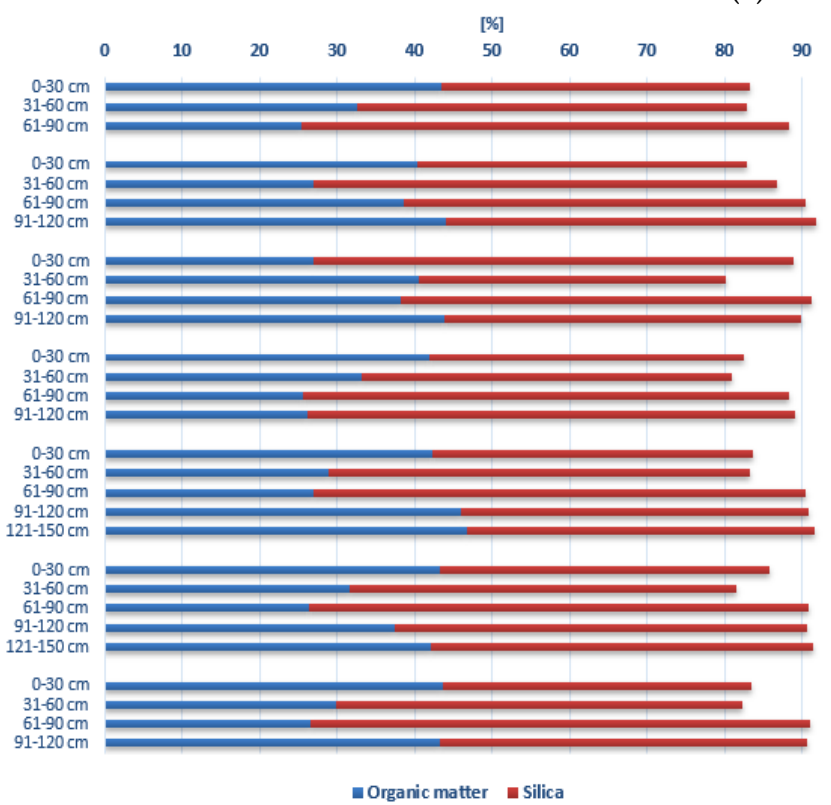

(d)
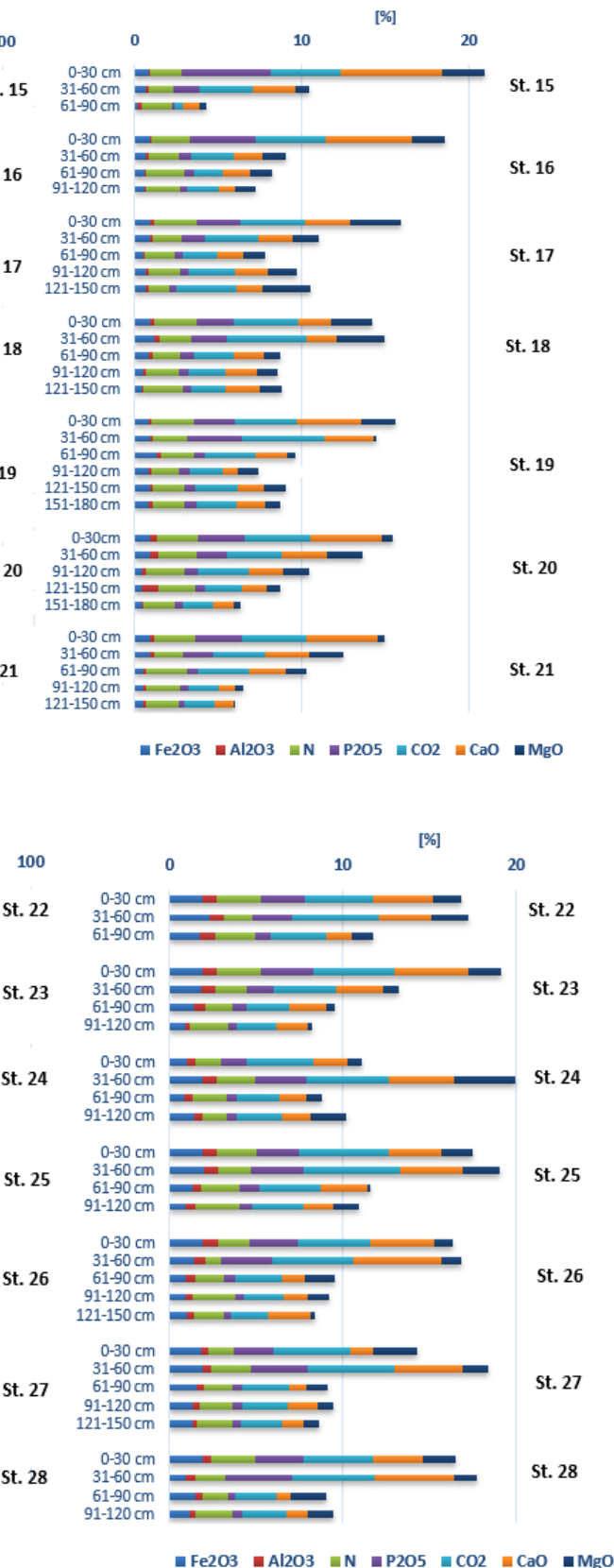

Figure 8. (a) The mean chemical composition of bottom sediment of Karczemne Lake-Stations 1-7; (b) the mean chemical composition of bottom sediment of Karczemne Lake-Stations 8-14; (c) the mean chemical composition of bottom sediment of Karczemne Lake-Stations 15-21 and (d) the mean chemical composition of bottom sediment of Karczemne Lake-Stations 22-28.

\subsection{Phosphorus Fractions in the Bottom Sediments}

The analysis of particular phosphorus percentages of the total phosphorus showed that the dominant types were $\mathrm{NaOH}-\mathrm{nrP}$ (phosphorus associated with organic matter), which made up over $82 \%$ of TP at research point number 5 , and calcium-related phosphorus (HCl-P), whose presence at points 24,26 and 28 exceeded $45 \%$ of the TP. Residual phosphorus (res-P) made up $25 \%$ of the TP at some research points, and at point 14 , it exceeded $35 \%$ in the $30-60 \mathrm{~cm}$ layer.

Additionally, the $\mathrm{NaOH}-\mathrm{rP}$ fraction (phosphorus bound mainly with aluminum) at some sites occurred in higher amounts, exceeding $20 \%$ of the TP. These fractions are moderately biologically 
available ( $\mathrm{NaOH}-\mathrm{rP}$ and $\mathrm{NaOH}-\mathrm{nrP})$, poorly available $(\mathrm{HCl}-\mathrm{P})$ or biologically inaccessible (res-P; Figure 9).

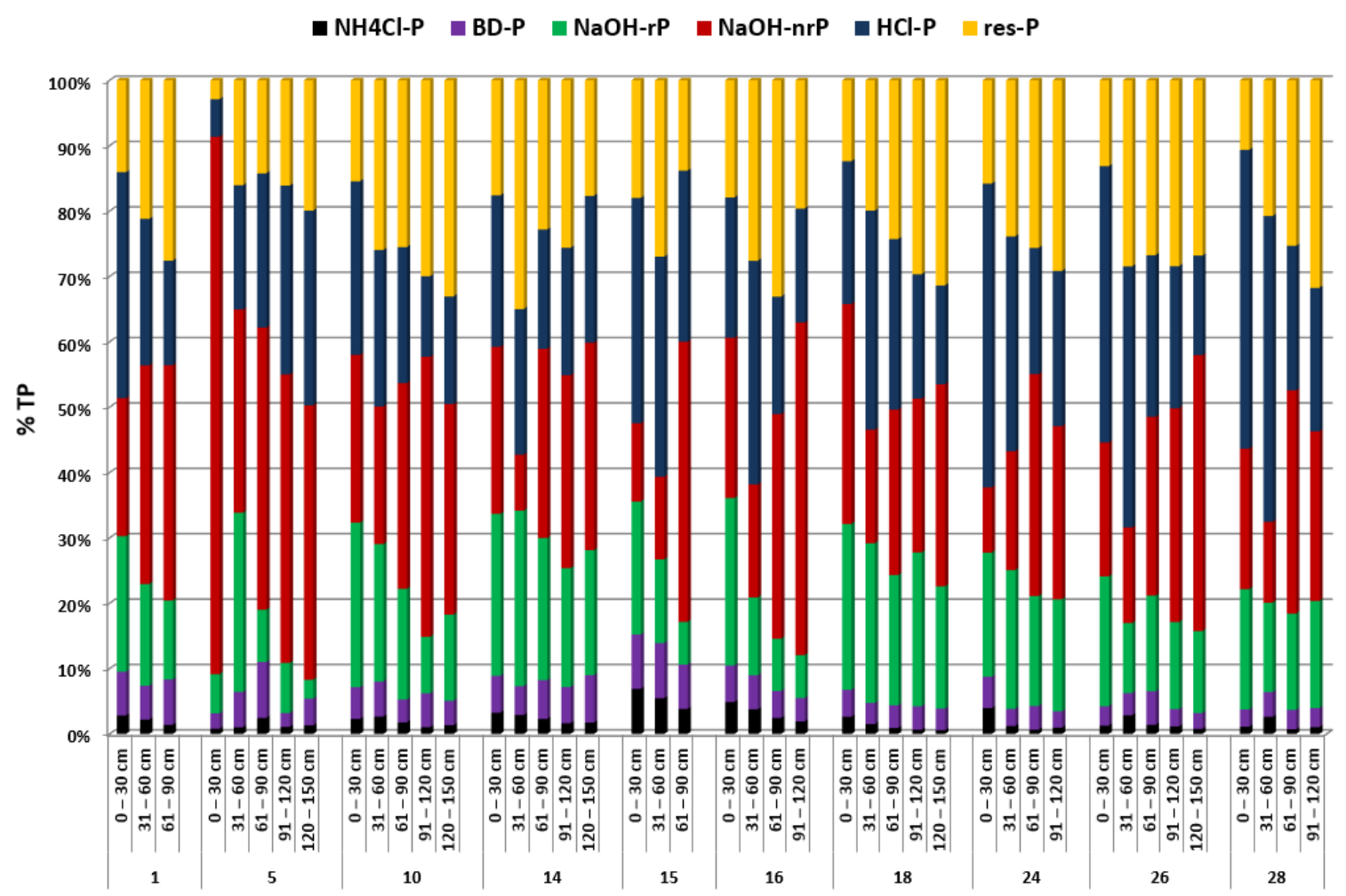

Figure 9. Share of phosphorus fractions (as \%TP) at selected bottom sediment research stations.

The most mobile fractions of phosphorus- $\mathrm{NH}_{4} \mathrm{Cl}-\mathrm{P}$ (phosphorus loosely bound to sediment) and BD-P (phosphorus sensitive to redox potential changes)-made up a small percentage of the total phosphorus (typically only a few percent). However, due to the extremely high content of total phosphorus in the surface layer of sediments, a few percent of the TP translates into very high mobile phosphorus content, especially in the case of the BD-P fraction; at several research points, the content of this fraction was higher than $2.5 \mathrm{mg} \mathrm{P} \mathrm{g}^{-1} \mathrm{~d}$.w. (Figure 9). These values indicate a serious threat to the quality of Karczemne Lake water. In addition, $\mathrm{NaOH}-\mathrm{rP}$ and $\mathrm{NaOH}-\mathrm{nrP}$ were present in very high proportions in the studied sediments. These fractions are mobilized by the increased reaction in the interphase water. In a polluted reservoir such as Karczemne Lake, with its low depth and polymictic water dynamics, intense photosynthesis may affect the increase in $\mathrm{pH}$ in the sediment waters (interphase) and thus stimulate an internal supply of phosphorus from the $\mathrm{NaOH}-\mathrm{rP}$ and $\mathrm{NaOH}-\mathrm{nrP}$ fractions (Figure 9).

3.6. Stable Organic Pollutants (POPs), Polycyclic Aromatic Hydrocarbons (PAHs) and Heavy Metal Contents in the Sediments

In sample No. 1, taken from research points 1-15 from layers a $(0-30 \mathrm{~cm})$ and $\mathrm{b}(31-60 \mathrm{~cm})$, exceedances were found in the content of benzo (a) pyrene- $-1.21 \mathrm{mg} \mathrm{kg}^{-1} \mathrm{~d} . \mathrm{w}$. in the ratio to the standard of $1.0 \mathrm{mg} \mathrm{kg}^{-1}$ d.w.; benzo (b) fluoranthene- $1.88 \mathrm{mg} \mathrm{kg}^{-1}$ d.w., compared to the norm of $1.5 \mathrm{mg} \mathrm{kg}^{-1}$ d.w.; benzo (g, h, i) perylene- $1.44 \mathrm{mg} \mathrm{kg}^{-1}$ d.w., compared to the norm of $1.0 \mathrm{mg} \mathrm{kg}^{-1}$ d.w. and indeno (1, 2, 3-cd) pyrene- $1.75 \mathrm{mg} \mathrm{kg}^{-1}$ d.w., compared to the norm of $1.0 \mathrm{mg} \mathrm{kg}^{-1}$ d.w. (Table 3$)$.

In sample No. 3, taken from research points 16-28 from layers a $(0-30 \mathrm{~cm})$ and b $(31-60 \mathrm{~cm})$, exceedances were found in the content of benzo (a) pyrene- $2.10 \mathrm{mg} \mathrm{kg}^{-1} \mathrm{~d}$.w. in the ratio to the standard of $1.0 \mathrm{mg} \mathrm{kg}^{-1} \mathrm{~d}$.w.; benzo (a) anthracene-1.69 $\mathrm{mg} \mathrm{kg}^{-1}$ d.w., compared to the norm of $1.5 \mathrm{mg} \mathrm{kg}^{-1}$ d.w.; benzo (b) fluoranthene- $3.57 \mathrm{mg} \mathrm{kg}^{-1}$ d.w. in ratio to the standard- $1.5 \mathrm{mg} \mathrm{kg}^{-1}$ 
d.w.; benzo ( $\mathrm{g}, \mathrm{h}, \mathrm{i})$ perylene- $-2.65 \mathrm{mg} \mathrm{kg}{ }^{-1}$ d.w., compared to the norm of $1.0 \mathrm{mg} \mathrm{kg}^{-1} \mathrm{~d} . \mathrm{w}$. and indeno $(1,2,3-\mathrm{cd})$ pyrene- $1.86 \mathrm{mg} \mathrm{kg}^{-1} \mathrm{~d}$.w., compared to the standard of $1.0 \mathrm{mg} \mathrm{kg}^{-1} \mathrm{~d} . \mathrm{w}$.

Table 3. Organic pollutants and heavy metal contents in bottom sediment of Karczemne Lake.

\begin{tabular}{ccccccc}
\hline Parameter & Norm & SampleNo. 1 & SampleNo. 2 & SampleNo. 3 & SampleNo. 4 & SampleNo. 5 \\
\hline $\mathrm{As}$ & $<30 \mathrm{mg} / \mathrm{kg}$ d.w. & 9.77 & 5.0 & 13.3 & 6.05 & 12.7 \\
\hline $\mathrm{Cr}$ & $<200 \mathrm{mg} / \mathrm{kg}$ d.w. & 29.1 & 18.8 & 40.1 & 33.2 & 44.1 \\
\hline $\mathrm{Zn}$ & $<1000 \mathrm{mg} / \mathrm{kg}$ d.w. & 406.0 & 104.0 & 503.0 & 152.0 & 843.0 \\
\hline $\mathrm{Cd}$ & $<7.5 \mathrm{mg} / \mathrm{kg}$ d.w. & 0.543 & 0.050 & 0.794 & 0.050 & 0.846 \\
\hline $\mathrm{Cu}$ & $<150 \mathrm{mg} / \mathrm{kg}$ d.w. & 93.5 & 25.9 & 123.0 & 38.4 & 247.0 \\
\hline $\mathrm{Ni}$ & $<75 \mathrm{mg} / \mathrm{kg}$ d.w. & 19.9 & 13.8 & 25.8 & 21.9 & 22.5 \\
\hline $\mathrm{Pb}$ & $<200 \mathrm{mg} / \mathrm{kg}$ d.w. & 97.2 & 31.6 & 126.0 & 49.4 & 317.0 \\
\hline $\mathrm{Hg}$ & $<1.0 \mathrm{mg} / \mathrm{kg}$ d.w. & 0.60 & 0.22 & 0.68 & 0.26 & 0.30 \\
\hline Benzo(a) anthracene & $<1.5 \mathrm{mg} / \mathrm{kg}$ d.w. & 1.13 & 0.361 & 1.69 & 0.240 & 13.0 \\
\hline Benzo(b) fluoranthene & $<1.5 \mathrm{mg} / \mathrm{kg}$ d.w. & 1.88 & 0.69 & 3.57 & 0.55 & 14.40 \\
\hline Benzo(k) fluoranthene & $<1.5 \mathrm{mg} / \mathrm{kg}$ d.w. & 0.803 & 0.270 & 1.380 & 0.246 & 5.770 \\
\hline Benzo(g, h, i) perylene & $<1.0 \mathrm{mg} / \mathrm{kg}$ d.w. & 1.44 & 0.548 & 2.65 & 0.72 & 7.34 \\
\hline Benzo(a) pyrene & $<1.0 \mathrm{mg} / \mathrm{kg}$ d.w. & 1,21 & 0.410 & 2.10 & 0.39 & 9.75 \\
\hline Dibenzo(a, h) anthracene & $<1.0 \mathrm{mg} / \mathrm{kg}$ d.w. & 0.297 & 0.020 & 0.482 & 0.020 & 3.24 \\
\hline Indeno(1, 2, 3-c,d) pyrene & $<1.0 \mathrm{mg} / \mathrm{kg}$ d.w. & 1.75 & 0.976 & 1.86 & 0.916 & 8.03 \\
\hline
\end{tabular}

In sample No. 5, taken from research point 5 from layers a $(0-30 \mathrm{~cm})$ and $b(31-60 \mathrm{~cm})$, exceedances were found in the range of benzo (a) pyrene- $9.75 \mathrm{mg} \mathrm{kg}^{-1} \mathrm{~d}$.w., compared to the norm of $1.0 \mathrm{mg}$ $\mathrm{kg}^{-1}$ d.w.; benzo (a) anthracene-13.0 mg kg-1 d.w., compared to the norm of $1.5 \mathrm{mg} \mathrm{kg}^{-1}$ d.w.; benzo (b) fluoranthene-14.4 $\mathrm{mg} \mathrm{kg}^{-1}$ d.w., compared to the norm of $1.5 \mathrm{mg} \mathrm{kg}^{-1}$ d.w.; benzo $(\mathrm{g}$, h, i) perylene- $7.34 \mathrm{mg} \mathrm{kg}^{-1}$ d.w., compared to the norm of $1.0 \mathrm{mg} \mathrm{kg}^{-1} \mathrm{~d}$.w.; benzo (k) fluoranthene-5.77 $\mathrm{mg} \mathrm{kg}^{-1}$ d.w., compared to the norm of $1.5 \mathrm{mg} \mathrm{kg}^{-1}$ d.w dibenzo $(\mathrm{a}, \mathrm{h})$ anthracene- $3.24 \mathrm{mg} \mathrm{kg}^{-1}$ d.w., compared to the norm of $1.0 \mathrm{mg} \mathrm{kg}^{-1}$ d.w.; indeno $(1,2,3-\mathrm{cd})$ pyrene- $-8.03 \mathrm{mg} \mathrm{kg}^{-1}$ d.w., compared to the norm of $1.0 \mathrm{mg} \mathrm{kg}^{-1}$ d.w.; $\mathrm{Cu}-247 \mathrm{mg} \mathrm{kg}^{-1}$ d.w., compared to the standard of $150 \mathrm{mg} \mathrm{kg}^{-1} \mathrm{~d}$.w. and $\mathrm{Pb}-317 \mathrm{mg} \mathrm{kg}^{-1}$ d.w., compared to the standard of $200 \mathrm{mg} \mathrm{kg}^{-1}$ d.w.

In samples No. 2, 4 and 6, exceedances beyond the limit values were not found (Table 3).

With reference to the regulation, $40 \%$ of the bottom sediment of Karczemne Lake did not meet the requirements of uncontaminated spoil (code in the waste catalog 170506 ) and constituted a dangerous sediment, i.e., catalog code 1705 05, and should be disposed by incineration. Sixty percent of the output could be transferred for further use after prior dilution, i.e., mixing with sediments formed during the wastewater treatment process. In the case of introducing it to the ground (leveling, reclamation and fertilization), the provisions of the OME [38] on the method of conducting the assessment of the ground surface pollution indicate that dredged spoil on the surface of the earth cannot make the original classification of the soil or soil quality change as a result of its deposit.

\subsection{Mass Calculation}

The results of the research on the spatial variability of phosphorus content and its fractions in the Karczemne Lake sediments enabled the precise determination of sediment layers that need to be removed from particular sectors of the ecosystem bottom. The deposit thicknesses indicated for removal in each of the separated bottom sediment sectors are presented in Table 4. Considering the sector areas and the thickness of the layer to be removed, the volume of deposits to be dredged from Karczemne Lake was $240013 \mathrm{~m}^{3}$ (Table 4). Based on the density of the sediment and the degree of hydration, it was estimated that the fresh mass of the output will be 2,588,054.7 Mg and that the dry weight of the output will be $2691.35 \mathrm{Mg}$ (Table 4). The amount of nutrients that will be removed from the ecosystem along with the sediments and interstitial waters will be $212.86 \mathrm{Mg}$ of phosphorus and 405.67 Mg of nitrogen (Table 5). 
Table 4. Characteristics of physical parameters of bottom sediments with respect to the spatial volume balance and the mass of potential output to be removed.

\begin{tabular}{|c|c|c|c|c|c|}
\hline $\begin{array}{c}\text { Number of Sampling } \\
\text { Point }\end{array}$ & $\begin{array}{l}\text { Sector Area } \\
\left(\mathrm{m}^{2}\right)\end{array}$ & $\begin{array}{l}\text { The Thickness of } \\
\text { Layer to Be Removed } \\
\text { (m) }\end{array}$ & $\begin{array}{l}\text { Volume of the Layer } \\
\text { to Be Removed } \\
\left(\mathrm{m}^{3}\right)\end{array}$ & $\begin{array}{l}\text { Wet Sludge Mass to } \\
\text { Be Removed } \\
\left(\mathrm{kg} \mathrm{m}^{-2}\right)\end{array}$ & $\begin{array}{l}\text { Dry Sludge Mass to } \\
\text { Be Removed } \\
\left(\mathrm{kg} \mathrm{m}^{-2}\right)\end{array}$ \\
\hline 1 & 10,273 & 0.5 & 5136.5 & $5,575,868.5$ & $710,711.3$ \\
\hline 2 & 15,100 & 0.5 & 7550 & $828,312.1$ & $1,516,022.2$ \\
\hline 3 & 6000 & 0.5 & 3000 & $4,413,593.9$ & $2,830,379.8$ \\
\hline 4 & 11,345 & 0.6 & 6807 & $722,245.9$ & $437,108.8$ \\
\hline 5 & 11,495 & 0.6 & 6897 & $7,727,772.4$ & $1,394,499.5$ \\
\hline 6 & 12,500 & 0.6 & 7500 & $7,980,278.1$ & $703,813.3$ \\
\hline 7 & 18,600 & 0.6 & 11,160 & $1,216,534.6$ & $962,287.8$ \\
\hline 8 & 8200 & 0.5 & 4100 & $5,010,261.5$ & $1,811,746.2$ \\
\hline 9 & 15,900 & 0.6 & 9540 & $9,947,672.0$ & $1,012,203.0$ \\
\hline 10 & 14,770 & 0.75 & $11,077.5$ & $1,136,233.6$ & $1,022,676.0$ \\
\hline 11 & 6080 & 0.6 & 3648 & $385,594.4$ & $379,970.6$ \\
\hline 12 & 16,100 & 0.6 & 9660 & $1,014,576.2$ & $886,400.8$ \\
\hline 13 & 12,800 & 0.75 & 9600 & $10,225,571.2$ & $923,673.7$ \\
\hline 14 & 9280 & 0.9 & 8352 & $8,857,878.2$ & $672,286.9$ \\
\hline 15 & 10,650 & 0.6 & 6390 & $6,914,467.2$ & $634,595.0$ \\
\hline 16 & 13,600 & 0.5 & 6800 & $8,700,205.6$ & $682,288.6$ \\
\hline 17 & 15,950 & 0.6 & 9570 & $10,052,152.6$ & $817,790.2$ \\
\hline 18 & 5020 & 0.9 & 4518 & $4,794,241.8$ & $445,579.2$ \\
\hline 19 & 6900 & 0.75 & 5175 & $5,566,142.9$ & $402,880.1$ \\
\hline 20 & 11,900 & 0.9 & 10,710 & $11,550,996.8$ & $952,646.0$ \\
\hline 21 & 12,880 & 0.9 & 11,592 & $12,182,956.9$ & $979,039.5$ \\
\hline 22 & 11,540 & 0.75 & 8655 & $9,116,970.7$ & $719,112.3$ \\
\hline 23 & 12,670 & 0.75 & 9502.5 & $10,270,607.7$ & $912,577.6$ \\
\hline 24 & 16,100 & 0.9 & 14,490 & $15,329,075.7$ & $1,277,107.1$ \\
\hline 25 & 11,600 & 0.9 & 10,440 & $11,070,268.6$ & $945,021.8$ \\
\hline 26 & 23,750 & 0.6 & 14,250 & $15,094,698.4$ & $1,111,633.9$ \\
\hline 27 & 26,320 & 0.6 & 15,792 & $16,859,229.9$ & $1,158,047.5$ \\
\hline 28 & 13,500 & 0.6 & 8100 & $8,529,586.9$ & $615,247.2$ \\
\hline Total & 360,823 & - & 240,013 & $2,588,054.7 \mathrm{Mg}$ & $269,173.5 \mathrm{Mg}$ \\
\hline
\end{tabular}

Table 5. The load of phosphorus and nitrogen can be withdrawn from the Karczemne Lake with bottom sediments and interstitial water.

\begin{tabular}{|c|c|c|c|c|c|c|c|c|c|}
\hline \multirow{2}{*}{$\begin{array}{c}\text { Number of } \\
\text { Sampling } \\
\text { Point }\end{array}$} & \multirow{2}{*}{$\begin{array}{c}\text { Sector } \\
\text { Area } \\
\left(\mathrm{m}^{2)}\right.\end{array}$} & \multicolumn{2}{|c|}{$\begin{array}{l}\text { The Content of TP } \\
\text { in Bottom Sediment }\end{array}$} & \multicolumn{2}{|c|}{$\begin{array}{l}\text { The Content of TN } \\
\text { in Bottom Sediment }\end{array}$} & \multicolumn{2}{|c|}{$\begin{array}{l}\text { The Content of TP } \\
\text { in Interstitial Water }\end{array}$} & \multicolumn{2}{|c|}{$\begin{array}{l}\text { The Content of TN } \\
\text { in Interstitial Water }\end{array}$} \\
\hline & & $\mathrm{kg} \mathrm{P} \mathrm{m}^{-2}$ & kg P sector ${ }^{-1}$ & $\mathrm{~kg} \mathrm{~N} \mathrm{~m}^{-2}$ & kg N sector ${ }^{-1}$ & $\mathrm{gP} \mathrm{m}^{-2}$ & kg P sector ${ }^{-1}$ & $\mathrm{~g} \mathrm{~N} \mathrm{~m}^{-2}$ & $\mathrm{~kg} \mathrm{~N}$ sector $^{-1}$ \\
\hline 1 & 10,273 & 0.46 & 4691.2 & 0.94 & 9697.7 & 1.62 & 16.66 & 10.60 & 109.28 \\
\hline 2 & 15,100 & 0.49 & 7468.5 & 1.12 & $16,966.2$ & 1.45 & 21.86 & 7.68 & 116.02 \\
\hline 3 & 6000 & 0.6 & 3769.7 & 1.47 & 8830.2 & 0.68 & 4.06 & 5.11 & 30.67 \\
\hline 4 & 11,345 & 0.48 & 5439.5 & 0.83 & 9365.5 & 1.52 & 17.25 & 13.70 & 155.35 \\
\hline 5 & 11,495 & 2.09 & $24,007.2$ & 1.15 & $13,180.0$ & 3.34 & 38.44 & 22.60 & 259.46 \\
\hline 6 & 12,500 & 0.55 & 6874.1 & 0.89 & $11,157.5$ & 1.92 & 24.06 & 14.10 & 176.74 \\
\hline 7 & 18,600 & 0.36 & 6636.8 & 0.90 & $16,760.7$ & 1.07 & 19.94 & 11.80 & 219.26 \\
\hline 8 & 8200 & 0.45 & 3657.5 & 0.49 & 4050.8 & 0 & 0 & 0 & 0 \\
\hline 9 & 15,900 & 0.52 & 8290.4 & 1.10 & $17,477.6$ & 2.03 & 32.25 & 8.33 & 132.49 \\
\hline 10 & 14,770 & 0.46 & 6825.0 & 1.24 & $18,387.5$ & 1.61 & 23.82 & 11.90 & 176.41 \\
\hline 11 & 6080 & 0.92 & 5622.0 & 1.02 & 6223.1 & 0.95 & 5.77 & 3.81 & 23.15 \\
\hline 12 & 16,100 & 0.40 & 6495.5 & 1.05 & $16,854.2$ & 1.03 & 16.55 & 14.40 & 232.24 \\
\hline 13 & 12,800 & 0.49 & 6276.8 & 1.44 & $18,369.0$ & 1.62 & 20.75 & 17.90 & 229.39 \\
\hline 14 & 9280 & 0.79 & 7361.0 & 1.48 & $13,706.1$ & 1.75 & 16.24 & 33.70 & 312.44 \\
\hline 15 & 10,650 & 0.77 & 8215.0 & 1.00 & $10,636.5$ & 1.53 & 16.26 & 8.28 & 88.22 \\
\hline 16 & 13,600 & 0.43 & 5860.4 & 0.97 & $13,139.7$ & 1.21 & 16.45 & 10.70 & 146.09 \\
\hline 17 & 15,950 & 0.39 & 6199.2 & 0.96 & $15,312.6$ & 0.68 & 26.87 & 9.01 & 143.67 \\
\hline 18 & 5020 & 0.57 & 2870.8 & 1.61 & 8087.3 & 2.04 & 10.22 & 27.20 & 136.37 \\
\hline 19 & 6900 & 0.59 & 4052.4 & 1.20 & 8280.0 & 2.57 & 17.71 & 27.20 & 187.60 \\
\hline 20 & 11,900 & 0.58 & 6852.3 & 1.62 & $19,283.5$ & 2.68 & 31.88 & 23.40 & 277.93 \\
\hline 21 & 12,880 & 0.52 & 6693.0 & 1.58 & $20,405.3$ & 1.91 & 24.61 & 22.60 & 291.16 \\
\hline 22 & 11,540 & 0.52 & 5952.7 & 1.31 & $15,134.8$ & 2.44 & 28.18 & 29.50 & 339.86 \\
\hline 23 & 12,670 & 0.55 & 6926.7 & 1.32 & $16,781.5$ & 1.90 & 24.07 & 16.80 & 213.24 \\
\hline 24 & 16,100 & 0.59 & 9531.7 & 1.57 & $25,236.6$ & 2.52 & 40.64 & 27.40 & 441.00 \\
\hline 25 & 11,600 & 0.73 & 8413.8 & 1.75 & $20,258.9$ & 2.84 & 32.94 & 36.50 & 423.60 \\
\hline 26 & 23,750 & 0.57 & $13,646.0$ & 0.55 & $12,975.1$ & 1.75 & 41.62 & 14.60 & 347.12 \\
\hline 27 & 26,320 & 0.54 & $14,224.2$ & 0.82 & $21,536.3$ & 2.51 & 66.03 & 21.90 & 576.67 \\
\hline 28 & 13,500 & 0.68 & 9168.3 & 0.85 & $11,464.8$ & 2.13 & 28.72 & 20.80 & 281.20 \\
\hline Total & 360,823 & - & $212.2 \mathrm{Mg}$ & $\begin{array}{c}- \\
\text { TOTAL P } \\
\text { TOTAL N }\end{array}$ & $\begin{array}{l}399.6 \mathrm{Mg} \\
212.86 \mathrm{Mg} \\
405.70 \mathrm{Mg}\end{array}$ & - & $0.66 \mathrm{Mg}$ & - & $6.07 \mathrm{Mg}$ \\
\hline
\end{tabular}




\section{Discussion}

The results of monitoring have shown that the water and bottom sediment of Karczemne Lake should be classified at the "below good" level. The lake does not meet the requirements of the Water Framework Directive of the European Union [41]. With such high nutrient concentrations and excess organic matter, the natural inhibition of the severe degradation of the lake is impossible. In addition to the very poor water quality, the bottom sediments of the analyzed lake also contain extremely high concentrations of pollutants. The concentrations of total phosphorus in the bottom sediments of Karczemne Lake were very high compared to those of other lakes [42-44]. To date, no other lake in Poland has recorded such high values of phosphorus. The maximum amount of total phosphorus was found at research point number 5: $31.8 \mathrm{mg} \mathrm{P} \mathrm{g}^{-1} \mathrm{~d} . \mathrm{w}$. in the surface sediments of layer a $(0-30 \mathrm{~cm})$. Bojakowska [45] reported that in Karczemne Lake sediments, a maximum of $1.9 \%$ TP in dry matter was found, which corresponds to $19 \mathrm{mg} \mathrm{P} \mathrm{g}^{-1} \mathrm{~d}$.w., while previous studies carried out by Grochowska et al. [46] showed a maximum of just over $12 \mathrm{mg} \mathrm{P} \mathrm{g}^{-1} \mathrm{~d}$.w. in the surface layer of sediments $(10 \mathrm{~cm}$ thick) taken from the deepest research point. For comparison, the maximum phosphorus content found by Kentzer [47] in the bottom sediment of dystrophic Zmarłe Lake was slightly above $10 \mathrm{mg} \mathrm{P} \mathrm{g}^{-1} \mathrm{~d}$.w. In the sediments of Długie Lake in Olsztyn, which was polluted for many years by domestic sewage, the level of phosphorus in the bottom sediments ranged from 4 to $6 \mathrm{mg}$ $\mathrm{P} \mathrm{g}^{-1}$ d.w. [48]. According to Sahin et al. [49], the amount of phosphorus in the sediments ranged from approximately 0.5 to $20.2 \mathrm{mg} \mathrm{P} \mathrm{g}^{-1} \mathrm{~d}$.w. However, Augustyniak [50] suggested that in the sediments of shallow lakes were not contaminated by sewage, the phosphorus content is usually low and does not exceed 2-3 $\mathrm{mg} \mathrm{P} \mathrm{g}^{-1}$ d.w. Karczemne Lake was a domestic sewage receiver for over 60 years. The pollution loads introduced with the sewage inflow deposited on the bottom of the reservoir forming a layer of so-called "modern sediments". In oligotrophic lakes, the thickness of the sediment increases by $1 \mathrm{~mm}$ each year, and in hypertrophic lakes, it increases by approximately $1 \mathrm{~cm} \mathrm{[50].}$ Such high phosphorus content in the bottom sediments, especially in the surface layer, is certainly the result of massive sewage pollution taking place over the last several decades. Station 5 , with the highest level of phosphorus, is located in the immediate vicinity of the collector discharging sewage into the lake, which for many years was the main source of pollution. It has been reported that in the deepest layers of the sediment (from $60 \mathrm{~cm}$ and in some positions from 90 to $150 \mathrm{~cm}$ deep into the sediment), the recorded amounts of total phosphorus are from approximately 0.5 (St. 5) to approximately $3 \mathrm{mg}$ $\mathrm{P} \mathrm{g}^{-1}$ d.w. (St. 18), which gives an overview of the concentration of total phosphorus before the pollution of the lake. Due to the low depth and polymictic nature of the reservoir bottom, sediment certainly undergoes resuspension, which in some sites could cause higher phosphorus contents in the deeper layer of sediment $(30-60 \mathrm{~cm})$, e.g., stations 24,26 and 28 . The vertical profiles of the phosphorus and total phosphorus fractions in the sediments at selected research stations show very rich concentrations of phosphorus in more detail as the deposit depth increases in Karczemne Lake. Theoretically, this phosphorus can easily be mobilized, providing a serious load of pollutants to the water of the analyzed reservoir.

\subsection{Reduction in Pollution Loads by Protective Methods}

Currently, the sewage network of the city of Kartuzy is being modified, which is necessary to decrease the high nutrient loads from wastewater. In addition, renovation work is being carried out in the tributary to Karczemne Lake (Klasztorna Struga) and involves the regulation of the riverbed and the fascine. In-stream and riparian vegetation will be restored in the channel. The aboveground parts of hydrophilic plants assimilate biogenic elements and increase aesthetic value [51]. In turn, the underground parts of plants (rhizomes and roots) release oxygen into the rhizosphere, which supports the processes of biodegradation of organic matter and nitrification, as well as biogenic substances. Glyceria maxima, Phalaris arundinacea and Phragmites australis will be planted in the channel of the Klasztorna Struga. The last protective action is the prohibition of angling baits. 
Applying all of the aforementioned solutions will result in a reduction in the external load of the lake by approximately $80 \%$.

\subsection{Conception of Restoration Treatments}

In the past, Karczemne Lake was overloaded by pollution from the catchment, which was a result of the long-term input of raw wastewater, including domestic, sanitary, storm and industrial waste. Under these conditions, it is necessary to use the optimal method of lake restoration after protection techniques are implemented in the catchment. The optimal restoration method for Karczemne Lake will be the removal of deposits due to their unusually high concentration of phosphorus. Additionally, for the stabilization of environmental conditions in the reservoir, the phosphorus inactivation method and biomanipulation will be applied.

For the purpose of restoration treatments in Karczemne Lake, there are separate extraction fields (10) in which the outputs of the liquid and solid fractions will be successively carried out for removal. The field currently undergoing the deposit removal process will be separated from the rest of the lake by a plastic curtain to prevent the movement of the deposit. The removal of the deposits will be carried out by a method with the use of an innovative device, the only type of equipment in Europe (suction dredge with wormwheel), precisely designed for lake dredging. Extracted output will be pumped to a pipeline on the northern shore of the lake and later by hydrotransport to a sewage treatment plant.

This technical solution guarantees prevention of the uncontrolled runoff of leachate back into the lake basin. The pipeline will be made of plastic (Figure 10).

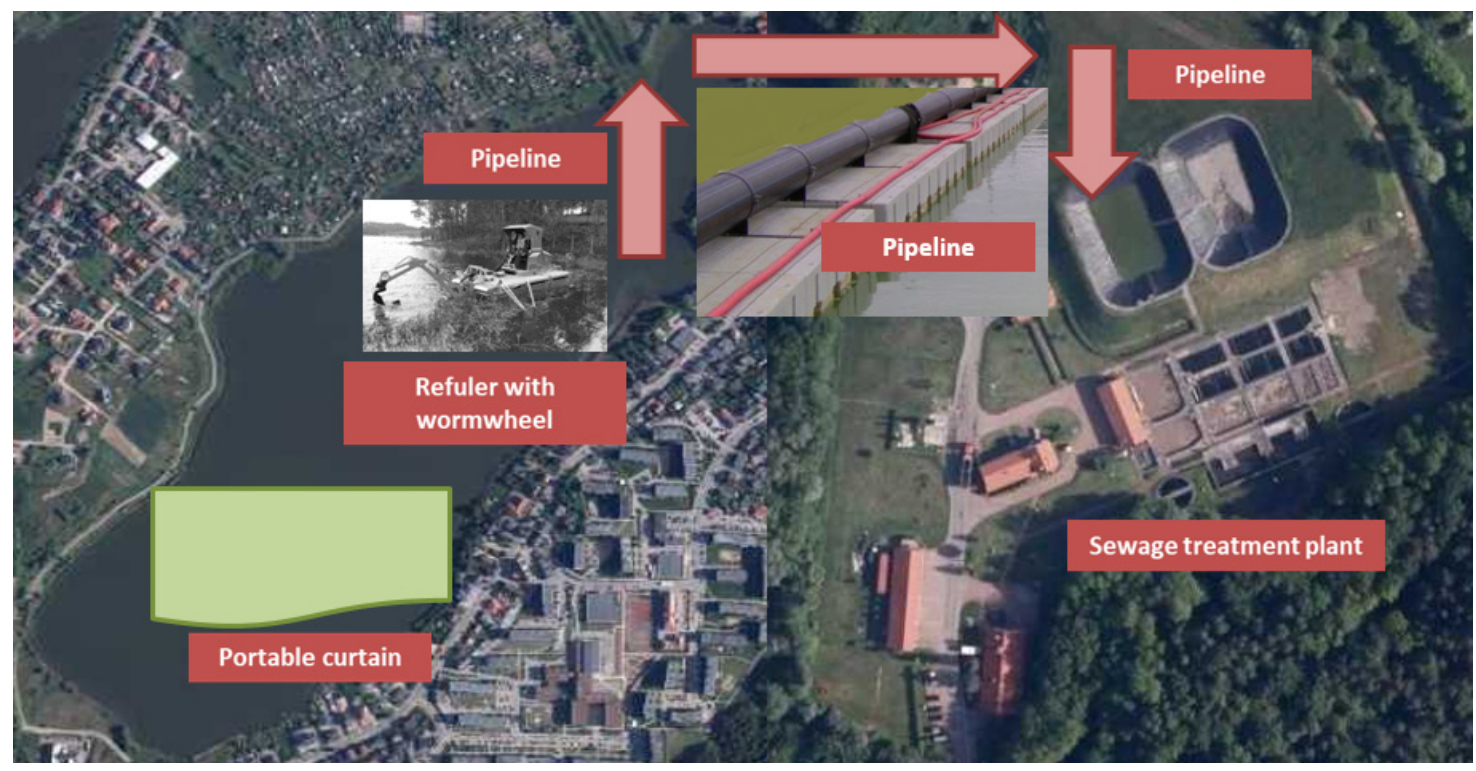

Figure 10. The scheme of planned restoration.

The proposed method does not require the construction of a completely new deposit treatment system consisting of presses, centrifuges, polymer-dosing stations, water-conditioning equipment and reaction pools (Figure 10).

In the sewage treatment plant, the sediment will be dehydrated in centrifuges and then subjected to hygienization. The part of the sediment that is contaminated with heavy metals will be transported for utilization.

Unpolluted sediments extracted from the lake and processed at the sewage treatment plant can also be valuable material for improving the soil structure, as they may contain premineralized organic compounds and easily digestible fertilizers, including macro- and microelements such as nitrogen, $1.5 \% \mathrm{~N}$; phosphorus 3, $5 \% \mathrm{P}_{2} \mathrm{O}_{5}$; calcium, $4.22 \% \mathrm{CaO}$; magnesium, $1.6 \% \mathrm{MgO}$ and iron, $1.8 \% \mathrm{Fe}_{2} \mathrm{O}_{3}$ 
(average contents of elements in dry mass of the Karczemne Lake sediments). Another form of deposit utilization can be the reclamation of degraded areas, for example, landfills [52-54].

In relation to the current level of external loads, the quantities of phosphorus and nitrogen that will be extracted from the lake during reclamation (loads coming with surface inflow, outlets of rainwater collectors, recreation and atmospheric precipitation) correspond to the amount of pollution that reaches the lake in 1300 years for phosphorus and 300 years for nitrogen. This confirms the validity of the assumptions behind the reclamation methods adopted, for which the priority was to remove the bottom sediments outside the ecosystem.

The removal of the bottom sediments from Karczemne Lake will be carried out within two years, from spring to the moment of the lake ice cover.

In the extraction field in which the sediment will be removed, the first phase of phosphorus inactivation to chemically precipitate pollutants distributed in the water column as a result of the dredging will be carried out. After the entire lake basin has been dredged, the next four stages of phosphorus inactivation (spring, autumn, spring and autumn) will be carried out. Based on the experience and research results obtained by the Department of Water Protection Engineering in the field of lake reclamation by phosphorus inactivation $[2,7,55,56]$, two types of coagulants will be dosed: PAX 18 and PIX 111. The doses of PIX and PAX coagulants were determined on the basis of the phosphorus fractions in the water and bottom sediments and the amount of natural components in the sediments having sorption capacity in relation to phosphorus, such as $\mathrm{Al}$, Fe and $\mathrm{Ca}[57,58]$.

The calculated doses of aluminum coagulant for Karczemne Lake were as follows: the area of the central zone of the lake was 20.0 ha, the volume of the central zone was $660,000 \mathrm{~m}^{3}$, the demand of the profundal sediment for aluminum was $23.6 \mathrm{~g} \mathrm{~m}^{-2}$, the demand for aluminum with which to bind the phosphorus in the water column in the central zone was $1650 \mathrm{~kg}$ and the total amount of reactive aluminum was $6370.8 \mathrm{~kg}$. The total dose of PAX 18 was $70,787.0 \mathrm{~kg}$.

Next, the dose of the iron coagulant for Karczemne Lake was calculated as follows: the area of the coastal zone was $20.4 \mathrm{ha}$, the volume of the coastal zone was $378,000 \mathrm{~m}^{3}$, the demand of the littoral deposits for iron was $44.26 \mathrm{~g} \mathrm{~m}^{-2}$, the demand for iron for binding the phosphorus in the water depth in the coastal zone was $945 \mathrm{~kg}$ and the total amount of reactive iron was $9974.0 \mathrm{~kg}$. The total dose of PIX 111 was $74,433.0 \mathrm{~kg}$.

To maintain the positive effects of restoration in Karczemne Lake, rational fish farming should be utilized. This method can be implemented through the use of biomanipulation, which involves the conscious shaping of the biocenosis of aquatic organisms by changing the species composition of ichthyofauna. The main goal of biomanipulation is to increase the number of large forms of zooplankton, mainly Cladocera, and through their control, feed the amount of phytoplankton, which are the first link in the trophic pyramid, thus reducing water blooms.

To achieve this effect, the number of sedentary fish, such as bleak, sunflower, small perch, juvenile roach, silverfish, bream and crucian, which feed on zooplankton or seek food in bottom sediments, should be limited. The reduction in these fish assemblies can be achieved, inter alia, through selective harvesting (without the use of towed tools). According to Gołdyn [59], at least 75\% of the initial fish should be harvested. This treatment should be intense and short term and should optimally occur within one year but no later than two years. The best effects result from the use of a large amount of pike fry. The recommended amount of recessed fry is at least 1000 pcs/ha [59], and the restocking material should have a size exceeding $10 \mathrm{~cm}$ because at this stage of development, the pike is going to feed on fish.

\section{Conclusions}

After detailed monitoring of the water and bottom sediment of Karczemne Lake, the methods proposed for protection and restoration of the lake discussed above enable us to realistically assess the potential opportunities for the renewal of severely degraded shallow, urban lakes. Considering the chemical composition of the water and bottom sediments of Karczemne Lake, external conditions, 
long-term economic and environmental aspects and the development of new technologies, it appears that an optimal variant of the approach taken to achieve permanent water quality improvement might consist of modernization of the urban sewerage system and restorative actions, including the removal of the bottom sediments from Karczemne Lake by a completely new, safe and economically justified method of mining and managing bottom sediments and phosphorus inactivation along with supportive actions in the form of biomanipulation. The technology of bottom sediment removal along with the construction of a hydrotransport pipeline, the phosphorus inactivation method and biomanipulation will have a total cost of US $\$ 2,100,000$.

Author Contributions: Conceptualization J.G. and M.Ł., investigation J.G., M.Ł., R.T., R.A., verification R.A. and R.T., writing-original draft preparation J.G. and R.A., writing-reviewing and editing J.G., R.A., M.Ł., R.T. All authors have read and agreed to the published version of the manuscript.

Funding: "Project financially supported by Minister of Science and Higher Educationin the range of the program entitled "Regional Iniciative of Excellence" for the years 2019—2022, project No. 010/RID/2018/19, amount funding 12.000.000 PLN".

Acknowledgments: Authors thank the Community of Kartuzy.

Conflicts of Interest: Authors declare no conflict of interest.

\section{References}

1. Grochowska, J.; Tandyrak, R.; Wiśniewski, G. Long-term hydrochemical changes in a lake after the application of several protection measures in the catchment. Pol. J. Nat. Sci. 2014, 29, 251-263.

2. Grochowska, J.; Augustyniak, R.; Łopata, M. How durable is the improvement of environmental conditions in a lake after the termination of restoration treatments. Ecol. Eng. 2017, 104, 23-29. [CrossRef]

3. Huser, B.J.; Futter, M.N.; Wang, R.; Fölster, J. Persistent and widespread long-term phosphorus declines in Boreal lakes in Sweden. Sci. Total Environ. 2018, 613-614, 240-249. [CrossRef] [PubMed]

4. Dodds, W.K.; Bouska, W.W.; Eitzmann, J.L.; Pilger, T.J.; Pitts, K.I.; Riley, A.J.; Schloesserv, J.A.; Thornbrugh, D.J. Eutrophication of U.S. freshwaters: Analysis of potential economic damages. Environ. Sci. Technol. 2009, 43, 12-19. [CrossRef]

5. Liu, D.; Wang, P.; Wei, G.; Dong, W.; Hui, F. Removal of algal blooms from freshwater by the coagulation-magnetic separation method. Environ. Sci. Pollut. Res. 2013, 20, 60-65. [CrossRef]

6. Huser, B.J.; Futter, M.; Lee, J.T.; Perniel, M. In-lake measures for phosphorus control: The most feasible and cost-effective solution for long-term management of water quality in urban lakes. Water Res. 2016, 97, 142-152. [CrossRef]

7. Grochowska, J.; Brzozowska, R.; Łopata, M. Durability of changes in phosphorus compounds in water of an urban lake after application of two reclamation methods. Water Sci. Technol. 2013, 68, 234-239. [CrossRef]

8. Grochowska, J.; Brzozowska, R. Influence of different recultivation methods on durability of nitrogen compounds changes in the waters of an urban lake. Water Environ. J. 2015, 29, 228-235. [CrossRef]

9. Dunalska, J.A.; Grochowska, J.; Wiśniewski, G.; Napiórkowska-Krzebietke, A. Can we restore badly degraded urban lakes? Ecol. Eng. 2015, 82, 432-441. [CrossRef]

10. Perkins, R.G.; Underwood, G.J.C. The potential for phosphorus release across the sediment-water interface in an eutrophic reservoir dosed with ferric sulphate. Water Res. 2001, 35, 1399-1406. [CrossRef]

11. Younhai, W.; Yajun, W.; Jianxin, Z.; Yunying, W. Phosphorus release from lake sediments: Effects of pH, temperature and dissolved oxygen. KSCE J. Civ. Eng. 2014, 18, 323-329.

12. Dunalska, J.A.; Wiśniewski, G. Can we stop the degradation of lakes? Innovative approaches in lake restoration. Ecol. Eng. 2016, 95, 714-722. [CrossRef]

13. Kajak, Z. Hydrobiology-Limnology. In Inland Water Ecosystems; PWN: Warsaw, Poland, 2002; pp. 1-212.

14. Lee, J.T. Minneapolis Chain of Lakes phosphorus reduction strategy. In Proceedings of the National Conference of Retrofit Opportunities for Water Resource Protection in Urban Environments, Chicago, IL, USA, 9-12 February 1998; USEPA, Office of Research Development: Washington, DC, USA, 1999. EPA/625/R-99/002.

15. Cooke, G.D.; Welch, E.B.; Peterson, S.A.; Newroth, P.R. Restoration and Management of Lakes and Reservoirs; Taylor \& Francis: Abingdon, UK; CRC Press: Boca Raton, FL, USA, 2005. 
16. Zamparas, M.; Zacharias, I. Restoration of eutrophic freshwater by managing internal nutrient loads. Sci. Total Environ. 2014, 496, 551-562. [CrossRef] [PubMed]

17. Rosińska, J.; Kozak, A.; Dondajewska, R.; Kowalczewska-Madura, K. Water quality response to sustainable restoration measures Case study of urban Swarzędzkie Lake. Ecol. Indic. 2018, 84, 437-449. [CrossRef]

18. Sheng-rui, W.; Xiangcan, J.; Haichao, Z.; Fengchang, W. Phosphorus fractions and its release in the sediments from the shallow lakes in the Middle and Lower Reaches of Yangtze River Area. Colloids Surf. A Physicochem. Eng. Asp. 2006, 273, 109-116.

19. Siwek, H. Speciation analysis of phosphorus in bottom sediments-comparison of two methods. J. Elem. 2010, 15, 161-170.

20. Xiaoli, W. Phosphorus fractionation and bio-availability in surface sediments from the Middle and Lower Reaches of the Yellow River. Procedia Environ. Sci. 2012, 12, 379-386.

21. Klapper, H. Technologies for lake restoration. J. Limnol. 2003, 62, 73-90. [CrossRef]

22. Environmental Monitoring Library. Report of the Voivodship Inspectorate for Environmental Protection; Environmental Monitoring Library: Bydgoszcz, Poland, 2003; pp. 1-182, ISBN 83-7217-204-8.

23. Björk, S. Lake restoration techniques-Proceedings of the International Congress on Lake Pollution and Recovery. In Proceedings of the European Water Pollution Control Association, Rome, Italy, 15-18 April 1985; pp. 202-212.

24. Björk, S.; Pokorný, J.; Hauser, V. Restoration of lakes through sediment removal, with case studies from lakes Trummen, Sweden and Vajgar, Czech Republic. In Restoration of Lakes, Streams, Floodplains, and Bogs in Europe. Principles and Case Studies; Eiseltová, M., Ed.; Springer: Berlin/Heidelberg, Germany, 2010.

25. Kondracki, J. Physical Geography of Poland; PWN: Warsaw, Poland, 2011; pp. 1-463.

26. Wołos, A.; Mioduszewska, H. Impact of anglers using groundbaits on fishing effects and nutrient balance of aquatic ecosystems. Fish. Announc. 2003, 1, 23-27.

27. Vollenweider, R.A. Advances In defining critical loading level for phosphorus in lake eutrophication. Mem. INST. Ital. Hydrobiol. 1976, 33, 53-83.

28. Carlson, R.E. A trophic state index for lakes. Limnol. Oceanogr. 1977, 22, 361-369. [CrossRef]

29. Kratzer, C.R.; Brezonik, P.L. A Carlson-Type trophic state index for nitrogen in Florida lakes. Water Res. Bull. 1981, 17, 713-715. [CrossRef]

30. Kaca, E. Measurements of water flow volume and mass of substance contained in it, and its uncertainty on the example of fish ponds. Water Environ. Rural Areas 2003, 13, 31-57.

31. Brzozowska, R.; Gawrońska, H. The influence of a long-term artificial aeration on th nitrogen compounds exchange between bottom sediments and water in Lake Długie. Oceanol. Hydrobiol. Stud. 2009, 38, 113-119. [CrossRef]

32. Rydin, E.; Welch, E.B. Aluminum dose required to inactivate phosphate in lake sediments. Water Res. 1998, 32, 2969-2976. [CrossRef]

33. Van Hullebush, E.; Auvray, F.; Deluchat, V.; Chazal, P.M.; Baudu, M. Phosphorus fractionation and short-term mobility in the surface sediment of a polymictic shallow lake treated with a low dose of alum (Courtille Lake, France). Water Air Soil Pollut. 2003, 146, 75-91. [CrossRef]

34. Hermanowicz, W.; Dożańska, W.; Dojlido, J.; Koziorowski, B.; Zerbe, J. Physico-Chemical Study of Water and Wastewater; Arkady: Warsaw, Poland, 1999.

35. Tibco Software Inc. STATISTICA Version 13.0. 2018. Available online: https://www.tibco.com/resources/ product-download/tibco-statistica-trial-download-windows (accessed on 5 June 2018).

36. EPA. Parameters of Water Quality. Interpretation and Standards; Environmental Protection Agency: Wexford, Ireland, 2001.

37. Wolfram MathWorld-web's most extensive mathematic. Available online: https://mathworld.wolfram.com/ VoronoiDiagram.html resources (accessed on 5 April 2020).

38. Ordinance of the Ministry of the Environment of 11 May 2015 on the recovery of waste outside installations and equipment. J. Laws 2015 (Set $\log 2015$, item 796); 2015. Available online: http://prawo.sejm.gov.pl/isap. nsf/download.xsp/WDU20150000796/O/D20150796.pdf resources (accessed on 5 April 2020).

39. Ordinance of the Ministry of the Environment of 1 September 2016 on the method of conducting an assessment of the soil surface pollution. J. Laws 2016 (Set $\log 2016$, item 1395); 2016. Available online: http: //prawo.sejm.gov.pl/isap.nsf/download.xsp/WDU20160001395/O/D20161395.pdf (accessed on 5 April 2020). 
40. Augustyniak, R.; Neugebauer, M.; Kowalska, J.; Szymański, D.; Wiśniewski, G.; Filipkowska, Z.; Grochowska, J.; Łopata, M.; Parszuto, K.; Tandyrak, R. Bottom deposits of stratified, seepage, urban lake (on the example of Tyrsko Lake, Poland) as a factor potentially shaping lake water quality. J. Ecol. Eng. 2015, 18, 55-62. [CrossRef]

41. Directive, W.F. Directive 2000/60/EC of the European Parliament and of the Council of 23 October 2000 establishing a framework for Community action in the field of water policy. Off. J. Eur. Communities 2000, 22, 1-73.

42. Kowalczewska-Madura, K.; Dondajewska, R.; Gołdyn, R.; Kozak, A.; Messyasz, B. Internal phosphorus loading from the bottom sediments of a dimictic lake during its sustainable restoration. Water Air Soil Pollut. 2018, 229. [CrossRef]

43. Smal, H.; Ligęza, S.; baran, S.; Wójcikowska-Kapusta, A.; Obroślak, R. Nitrogen and phosphorus in bottom sediments of two small dam reservoir. Pol. J. Environ. Stud. 2013, 22, 1479-1489.

44. Ishii, Y.; Yabe, T.; Nakamura, M.; Amano, Y.; Komatsu, N.; Watanabe, K. Effect of nitrate mobilization from bottom sediment in shallow eutrophic lakes. J. Water Environ. Technol. 2009, 7, 75-83. [CrossRef]

45. Bojakowska, I. Phosphorus in lake sediments of Poland-Results of monitoring research. Limnol. Rev. 2016, 16, 15-25. [CrossRef]

46. Grochowska, J.; Brzozowska, R.; Grzybowski, M.; Napiórkowska-Krzebietke, A.; Bigaj, I.; Szymański, D.; Zieliński, R. Physicochemical Tests of Water and Bottom Sediments as well as Hydrological Measurements of 4 Lakes: Mielenko, Tavern, Large and Small Monastery and Their Catchments in Terms of the Possibility of Reservoir Protection against Degradation; Commune Office in Kartuzy: Kartuzy, Poland, 2013; Typescript, not published data.

47. Kentzer, A. Phosphorus and Its Biologically Available Fractions in Lake Sediments of Various Trophies; UMC: Torun, Poland, 2001; pp. 1-111.

48. Brzozowska, R.; Gawrońska, H. Influence of a multi-year artificial aeration of a lake using destratification method on the sediment-water phosphorus exchange. Arch. Environ. Prot. 2005, 31, 71-88.

49. Şahin, Y.; Demirak, A.; Keskin, F. Phosphorus fractions and its potential release in the sediments of Koycegiz Lake, Turkey. Lakes Reserv. Ponds 2012, 6, 139-153.

50. Augustyniak, R. The Influence of Physico-Chemical and Microbiological Factors on Internal Supply of Phosphorus in Selected Urban Lakes; Committee of Environmental Engineering of the Polish Academy of Sciences: Lublin, Poland, 2018; Volume 140, pp. 1-230.

51. Jucherski, A.; Walczowski, A. Influence of selected macrophytes on sewage treatment effectiveness in the slope soil-vegetation filtration beds. Probl. Agric. Eng. 2012, 20, 115-124.

52. Gałka, B.; Witkowski, M. Characteristics of bottom sediments of the Młyny dam reservoir and the possibility of its agricultural use. Water Environ. Rural Areas 2010, 10, 53-63.

53. Maj, K.; Koszelnik, P. Methods of the management of bottom sediment. J. Civ. Eng. Environ. Archit. 2016, 63, 157-169.

54. Eymontt, A.; Wierzbicki, K. Hydromechanical technology of bottom sediment mining. Probl. Agric. Eng. 2017, 4, 19-27.

55. Gawrońska, H.; Łopata, M.; Jaworska, B. The effectiveness of the phosphorus inactivation method in reducing the trophy of lakes of different morphometrical and hydrological features. Limnol. Rev. 2007, 7, 27-34.

56. Grochowska, J.; Augustyniak, R.; Łopata, M.; Parszuto, K.; Tandyrak, R.; Płachta, A. From saprotrophic to clear water status: The restoration path of a degraded urban lake. Water Air Soil Pollut. 2019. [CrossRef]

57. Rydin, E.; Welch, E.B. Dosing alum to Wisconsin lake sediments based on in vitro formation of aluminum bound phosphate. Lake Reserv. Manag. 1999, 15, 324-331. [CrossRef]

58. Gawrońska, H.; Brzozowska, R.; Grochowska, J.; Lossow, K. Effectiveness of PAX and PIX coagulants in phosphorus reduction in a lake-Laboratory experiments. Limnol. Rev. 2001, 1, 73-82.

59. Gołdyn, R. Biomanipulation in water reservoirs as a method of reclamation. Munic. Rev. 2007, 6, 70-72.

(C) 2020 by the authors. Licensee MDPI, Basel, Switzerland. This article is an open access article distributed under the terms and conditions of the Creative Commons Attribution (CC BY) license (http://creativecommons.org/licenses/by/4.0/). 